Marquette University

e-Publications@Marquette

Finance Faculty Research and Publications

Business Administration, College of

$12-1-2010$

\title{
The Effect of Taxes on Multinational Debt Location
}

Matteo Arena

Marquette University, matteo.arena@marquette.edu

Andrew H. Roper

Cornerstone Research

Accepted version. Journal of Corporate Finance, Vol. 16, No. 5 (December 2010): 637-654. DOI. NOTICE: this is the author's version of a work that was accepted for publication in Journal of Corporate Finance. Changes resulting from the publishing process, such as peer review, editing, corrections, structural formatting, and other quality control mechanisms may not be reflected in this document. Changes may have been made to this work since it was submitted for publication. A definitive version was subsequently published in Journal of Corporate Finance, [VOL 16, ISSUE 1, February 2010] DOI. 


\title{
The Effect of Taxes on Multinational Debt Location
}

\author{
Matteo P. Arena* \\ Marquette University \\ Department of Finance \\ 312 Straz Hall \\ Milwaukee, WI 53201-1881 \\ Tel: (414) 288-3369 \\ E-mail: matteo.arena@mu.edu \\ Andrew H. Roper \\ Cornerstone Research \\ 1000 El Camino Real \\ Menlo Park, CA 94025 \\ Tel: (650) 470-7157 \\ E-mail: aroper@cornerstone.com
}

\begin{abstract}
We provide new evidence that differences in international tax rates and tax regimes affect multinational firms' debt location decisions. Our sample contains 8,287 debt issues from 2,437 firms headquartered in 23 different countries with debt-issuing subsidiaries in 59 countries. We analyze firms' marginal decisions of where to issue debt to investigate the influence of a comprehensive set of tax-related effects, including differences in personal and corporate tax rates, tax credit and exemption systems, and bi-lateral cross-country withholding taxes on interest and dividend payments. Our results show that differences in personal and corporate tax rates, the presence of dividend imputation or relief tax systems, the tax treatment of repatriated profits, and inter-country withholding taxes on dividends and interest significantly influence the decision of where to locate debt and the proportion of debt located abroad. Our results are robust to firm and issue specific factors and to the effect of legal regimes, debt market development, and exchange rate risk.
\end{abstract}

JEL Classifications: F23; F34; G15; G32

Keywords: International Corporate Finance, Capital Structure, International Debt Choice, Corporate Taxes, Withholding Taxes, FDI

* Corresponding author 


\title{
The Effect of Taxes on Multinational Debt Location
}

\begin{abstract}
We provide new evidence that differences in international tax rates and tax regimes affect multinational firms' debt location decisions. Our sample contains 8,287 debt issues from 2,437 firms headquartered in 23 different countries with debt-issuing subsidiaries in 59 countries. We analyze firms' marginal decisions of where to issue debt to investigate the influence of a comprehensive set of tax-related effects, including differences in personal and corporate tax rates, tax credit and exemption systems, and bi-lateral cross-country withholding taxes on interest and dividend payments. Our results show that differences in personal and corporate tax rates, the presence of dividend imputation or relief tax systems, the tax treatment of repatriated profits, and inter-country withholding taxes on dividends and interest significantly influence the decision of where to locate debt and the proportion of debt located abroad. Our results are robust to firm and issue specific factors and to the effect of legal regimes, debt market development, and exchange rate risk.
\end{abstract}

JEL Classifications: F23; F34; G15; G32

Keywords: International Corporate Finance, Capital Structure, International Debt Choice, Corporate Taxes, Withholding Taxes, FDI 


\section{The Effect of Taxes on Multinational Debt Location}

\section{Introduction}

Despite numerous empirical studies dealing with firms' capital structure choice in international debt markets, the prior literature has yet to fully consider the broad array of tax factors that theory predicts can influence a multinational firm's decision of where to locate debt. Prior studies, such as Desai et al. (2004) and Huizinga et al. (2008), have examined tax-related effects on firms' multinational capital structure decision. However, these studies consider only a subset of tax-related incentives that could influence the corporate debt location decision. Moreover, these studies use debt-related information for firms headquartered in a limited set of developed countries with many institutional similarities. Absent a more comprehensive investigation of tax-related incentives, the literature's understanding of the theoretical tax-related benefits of debt financing remains limited.

This study aims to increase the literature's understanding by considering a broader set of tax-related incentives of debt finance facing multinational firms located in disparate institutional settings. Specifically, we examine the impact of differences in corporate and personal tax rates and tax regimes on multinational firms' marginal decisions of whether to issue debt at home through the parent or a domestic subsidiary or abroad through a foreign subsidiary. Our analysis uses a unique dataset consisting of 8,287 debt issues between 1995 and 2004 from 2,437 firms headquartered in 23 different countries with debt-issuing subsidiaries in a total of 59 countries. 
Combined, this study's investigation of the tax-related incentives facing multinational firms provide a richer, more complete analysis of the influence of taxes on a firm's decision of where to locate debt.

We find that tax factors significantly affect multinational firms' decisions of where to locate debt as well as the proportion of debt that they locate abroad. Specifically, we find that a multinational firm is more likely to issue debt abroad when the firm's foreign subsidiary is located in a country in which debt capital is afforded a greater tax advantage, as measured by a proxy of the Miller (1977) gains-to-leverage formula (“debt tax gain”), and when the tax code permits dividend imputation or dividend relief. Our results on dividend imputation and relief are particularly noteworthy since, as noted by Graham (2008), as of today the effect of these dividend tax systems on debt location is empirically unknown despite their potentially significant influence in multinational capital structure decisions. We also find that firms are more likely to issue debt through foreign subsidiaries in high corporate tax countries when the parent country adopts an exemption system on repatriated profits from subsidiaries. ${ }^{1}$ Moreover, we show that the proportion of the total amount of debt issued by multinational firms via their foreign subsidiaries increases relative to the tax advantage of debt in the subsidiary's country and also depends on the presence of inter-country withholding taxes on interest income and dividends.

Our findings are consistent with the hypothesis that multinational firms locate debt in taxadvantaged countries in order to capture positive valuation effects and are robust after

\footnotetext{
${ }^{1}$ While there exists some empirical evidence on the effect of the US tax credit system on debt location decisions by US corporations (e.g., Newberry and Dhaliwal (2001)), our study is the first to investigate the effect of the tax exemption system (which is currently adopted by the great majority of countries in the world) on the location debt decision.
} 
controlling for a multitude of other factors. Our results display strong economic significance. For example, a firm headquartered in a country with dividend imputation and exemption tax systems and "debt tax gain" at the $25^{\text {th }}$ percentile is $41.5 \%$ more likely to issue debt in a country with a classical dividend tax system and "debt tax gain" at the $75^{\text {th }}$ percentile than in a country with a dividend imputation tax system and "debt tax gain" at the $25^{\text {th }}$ percentile.

These findings result from an empirical analysis of the tax incentives on corporate debt policy that has increased power over previous studies on international capital structure and corporate debt location choices (e.g., Booth et al. (2001), Demirguc-Kunt and Maksimovic (1988), Fan et al. (2008), Desai et al. (2004), and Huizinga et al. (2008)). ${ }^{2}$ First, we examine the within-firm variation in the decision of where to locate debt (i.e., domestic parent or subsidiary versus foreign subsidiary). Thus, our sample provides a natural control for firm-level variation that may influence capital structure decisions and are less likely to suffer from omitted variable biases.

Second, our sample examines the incremental marginal decision of where to locate debt as opposed to the extent of foreign versus domestic debt that exists within a firm's capital structure. Much of the prior literature that examines the effect of taxes of firms' debt to equity ratios uses available balance sheet information of firms located in different countries. By focusing on the marginal decision of where to locate debt, our tests provide more power to identify effects that are determined at the margin, such as taxes (MacKie-Mason (1990) and Graham (1996)). Moreover, the incremental approach links the borrowing decision of the firm

\footnotetext{
${ }^{2}$ As noted by Graham (1996), Auerbach (2002), and Graham (2003), the estimation of the sensitivity of capital structure to tax incentives has proven challenging.
} 
with variables measured prior to the debt issuance, allowing an analysis of the effect of timevariation in tax factors on the debt location choice. ${ }^{3}$

Third, we consider a more comprehensive set of possible tax effects than the prior literature. Our data contain detailed information on country-level corporate and personal income tax rates; inter-country dividend and interest withholding tax rates; a distinction between tax credit and exemption systems on repatriated profits from foreign subsidiaries; as well as categorical information regarding tax regimes, i.e., dividend relief versus dividend imputation regimes.

Finally, our data aggregate firm- and country-specific information across a variety of sources in order to control for possible additional explanations of multinational firms' decisions of where to locate debt. For example, our data merge information from Thomson Financial's Security Data Corporation's (“SDC”) Global New Issues Database, Compustat Global, annual publications of PricewaterhouseCoopers' ("PwC”) Corporate Taxes a Worldwide Summary, LexisNexis Corporate Affiliations, the International Monetary Fund's International Financial Statistics, and the World Bank's World Development Indicators, among others. Combined, our data contain contract-related information (e.g., issue size and issue type), firm-specific accounting information at the parent and subsidiary level (e.g., firm size, leverage, and profitability), and information related to country-level differences in credit markets, legal environments, and interest rate or exchange rate risk environments. To our knowledge, the data of this study is the most comprehensive in the literature in terms of the number of countries

\footnotetext{
${ }^{3}$ Denis and Mihov (2003), Arena and Howe (2009), and Arena (2010) use a similar approach to analyze the publicprivate debt choice for U.S. firms.
} 
studied, the number of firms considered, and the level of tax-related and institutional-related information.

While not the focus of this paper, our tests also consider additional motives for locating debt abroad. In particular, we show that companies are more likely to issue debt abroad through subsidiaries that post high profits relative to their parents' reported consolidated profits. We find multinationals headquartered in countries with developed debt markets are less likely to issue debt abroad. We also find that multinational firms headquartered in common law countries are less likely to issue debt through foreign subsidiaries, especially if these foreign subsidiaries are located in civil law countries or in countries with poorer rule of law. Conversely, multinational firms headquartered in civil law countries are more likely to issue debt through foreign subsidiaries whenever the subsidiary is located in a common law country. These findings are consistent with the hypotheses that firms locate debt in subsidiaries that have higher potential tax benefits to debt, and that firms are willing to commit to more restrictive standards for corporate governance by issuing debt in international markets (Harvey et al. (2004)), and that firms attempt to arbitrage differences in the cost of debt finance resulting from international differences in credit market institutions (Noe (2000) and Titman (2002)). In addition, we show that debt location choice is also explained by the exchange rate risk. A company is more likely to issue debt through a subsidiary located in a foreign country with higher exchange rate risk than the parent country. This result is consistent with the hypothesis that firms locate debt in countries in an attempt to hedge the impact of foreign exchange movements on operating results. 
Of the studies that examine debt policy within multinational firms, Desai et al. (2004) and Huizinga et al. (2008) are the most related. ${ }^{4}$ Using affiliate level data for U.S. multinationals, Desai et al. (2004) provide evidence that higher local tax rates are correlated with affiliate-level higher debt-to-asset ratios. Huizinga et al. (2008) document the ability of differences in international tax rates to explain the cross-sectional variation of leverage ratios observed in European firms.

In contrast to these papers, we examine the impact of taxes on multinational firms' marginal decision of where to locate debt using an analysis of the within-firm variation in debt issue location. We also investigate for the first time in the literature the effect of personal taxes, withholding taxes on interest income, tax credit and exemption systems, and dividend imputation and dividend relief tax regimes on the debt location choice. Moreover, we greatly extend prior samples to include firms from both developed and developing markets. Finally, we examine taxbased incentives on the choice of debt location while controlling for a broader set of factors that may also be related to location choice. Combined, these contributions allow us to provide new evidence that broadens our understanding of the impact of corporate taxes and the corporate tax environment on a firm's debt location choice.

The rest of this paper is organized as follows. Section 2 presents the empirical questions related to the tax factors that may affect a multinational firm's decision of where to locate debt. Section 3 outlines our sample selection requirements and provides summary statistics and

\footnotetext{
${ }^{4}$ Other related studies that examine the tax incentives to debt location in multinational corporations are Chowdhry and Nanda (1994), Chowdhry and Coval (1998), Newberry (1998), and Newberry and Dhaliwal (2001).
} 
univariate analysis. Section 4 provides our multivariate analysis of factors that determine a firm's choice of where to locate debt. Section 5 reports robustness checks. Section 6 concludes.

\section{Taxes and the Decision of Where to Issue Debt}

In this section we present our tax-related empirical questions and describe the variables used in our empirical analysis to investigate those questions.

\subsection{Net Tax Advantage of Domestic Debt to Foreign Debt Due to Corporate and Personal Taxes}

Differences in corporate and personal tax rates across countries can impact a firm's decision of where to locate debt. Hodder and Senbet (1990) demonstrate that when debt markets are not fully integrated, a Miller-type equilibrium results within each country while a pecking order results across national debt capital markets. However, if investors can freely move in and out of debt capital markets across different countries, investors' demand schedules for corporate debt can be aggregated across countries and taxes may not have a significant impact on a firm's choice of where to locate debt. Thus, whether or not taxes matter is an empirical question. Ceteris paribus, we conjecture that multinational corporations are more likely to offer debt in the countries with the highest net tax advantage to debt, where the net tax advantage includes the effects of both corporate and personal tax rates.

For example, consider a firm that has a subsidiary located in a foreign country. Both the parent and subsidiary generate taxable income. Assume interest payments on corporate debt are 
deductible against corporate income in both the foreign and domestic countries and that the corporate tax rates are $T_{C}^{\text {Domessic }}$ and $T_{C}^{\text {Foreign }}$ in the domestic and foreign countries respectively, $T_{C}^{\text {Domessic }}<T_{C}^{\text {Foreign }}$. Conditional on issuing debt, the net tax advantage of paying $\$ 1$ of interest in country $\mathrm{A}$, as opposed to country $\mathrm{B}$, is $\mathrm{T}_{\mathrm{A}}-\mathrm{T}_{\mathrm{B}}{ }^{5}$ Thus, all else equal, the firm has a relative tax advantage to issuing foreign debt relative to domestic debt due to differences in country-level corporate taxes.

The introduction of country-level personal taxes into the above hypothetical attenuates but does not eliminate the relative benefit to issuing foreign debt. This assumes that there exist frictions across markets such that country-level issuer demand for debt and country-level supply of debt capital do not aggregate into singular demand and supply curves for the world market for debt. As noted by Miller (1977), if the domestic country investor-level personal taxes on interest income are large relative to its tax rate on corporate income, the domestic country's relative tax advantage can be zero or even negative, all else equal. ${ }^{6}$ In general, one can compare the relative tax advantage to issuing debt in the domestic country versus the foreign country by comparing the outcome of the Miller (1977) gains to leverage formula across the two scenarios. ${ }^{7}$ Assume

\footnotetext{
${ }^{5}$ In practice, there may exist additional factors, outside the scope of this study, other than statutory tax rates that can affect the tax advantage of debt. For example, non-debt tax shields such as a firm's depreciation expense or tax loss carryforwards, and interest expense allocation rules can also affect a firm's decision to issue debt to the extent that they change a firm's marginal tax rate.

${ }^{6}$ We consider the tax effect on debt investors residing outside the subsidiary country or parent country by analyzing the effect of withholding taxes on interest as described in the following section.

${ }^{7}$ In tabulated results, we do not consider personal taxes on capital gains in our empirical application of the Miller's gains to leverage formula because in our sample the average parent ownership of subsidiaries is $92 \%$ and the great majority of foreign subsidiaries (84\%) are fully owned by the parent. Therefore in most cases there is not tradable subsidiary equity. Nonetheless, we have, in untabulated results, verified that our conclusions do not change if our Relative Debt Tax Gain variable is defined to include the impact of capital gains tax rates.
} 
the interest income is taxed at the same rate as personal income, identified as $T_{P}^{\text {Domessic }}$ and $T_{P}^{\text {Foreign }}$. Conditional of issuing debt, there exists a relative tax advantage to issuing debt in the foreign country whenever the following condition holds:

$$
1-\frac{\left(1-T_{C}^{\text {Domestic }}\right)}{\left(1-T_{P}^{\text {Domessic }}\right)}<1-\frac{\left(1-T_{C}^{\text {Foreign }}\right)}{\left(1-T_{P}^{\text {Foreign }}\right)}
$$

In our empirical analysis, we proxy for the relative tax advantage to issuing debt in the foreign country using the difference of the Miller (1997) gains-to-leverage ratio between the foreign subsidiary and the parent. This variable is labeled "Relative Debt Tax Gain." We create a proxy for $\mathrm{T}_{\mathrm{c}}$ using the maximum corporate tax rate reported for the parent's (subsidiary's) country of residence in PricewaterhouseCoopers's ("PwC") Corporate Taxes a Worldwide Summary in the year prior to the debt offering. We also create a proxy for $\mathrm{T}_{\mathrm{P}}$ using the maximum personal income tax rate reported in PwC's Individual Taxes a Worldwide Summary in the year prior to the debt offering for the parent's (subsidiary's) country of residence.

\subsection{The Effect of Dividend Imputation and Dividend Relief Systems}

In addition to the level of corporate and personal taxes, the tax treatments of dividend payments may be an important factor that influences a multinational firm's decision of where to locate debt. According to Fan et al. (2008), in the classical tax system dividend, payments are taxed at both the corporate and personal levels and interest payments are tax-deductible at the corporate level. The dividend relief tax system differs from the classical tax system in respect to 
the taxing of dividend payments, i.e., either dividends are not taxed at the corporate level or they are taxed at a reduced rate at the personal level. In dividend imputation tax systems, firms can deduct interest expenses at the corporate level, and domestic corporate taxes paid are distributed to taxable resident shareholders as a tax credit with dividend payments.

In the case of multinational corporations, deciding where to locate debt may vary according to the local dividend tax regime that applies to the parent and its subsidiary. For foreign subsidiaries that operate in dividend tax regimes in which after-tax cost of debt is more costly relative to equity (i.e., dividend imputation or dividend relief tax systems), the incentive to use debt finance is lower and multinational corporations will be less likely to consider issuing debt through these foreign subsidiaries. In this study we hypothesize that multinational corporations located in a country with a classical dividend tax system are less likely to locate debt in countries that adopt dividend imputation or dividend relief tax systems.

Following Fan et al. (2008), we classify Brazil, Hong Kong, India, Indonesia, Japan, Malaysia, Netherlands, Singapore, South Korea, Switzerland, and the United States as classical tax regimes; Sweden and Thailand as dividend relief tax regimes; and Australia, Canada, Finland, France, Germany, Italy, Mexico, Norway, Spain, Taiwan, and the United Kingdom as dividend imputation tax regimes. In our empirical analysis, we control for differences in tax rate regimes by creating a variable, "Relative Dividend Imputation," that equals one if the tax regime in the foreign country is a dividend imputation based system but the parent country is not; zero if both countries have tax regimes that are either dividend imputation systems or not; and minus 
one if the parent country is a dividend imputation system, but the foreign country is not. The variable "Relative Dividend Relief" is defined similarly.

\subsection{The Effect of Inter-Country Withholding Tax Rates on Dividends and Interest}

In addition to the above tax considerations, the domestic and foreign treatment of repatriated interest payments and dividend income may also influence the tax advantage of debt for a multinational firm and its debt location decision. For example, even though debt issued abroad may lower the foreign subsidiary's taxable income that is subject to the foreign country's corporate tax rate, any tax benefit to the parent may be affected if the foreign subsidiary must also pay withholding taxes on interest or dividend payments made to its domestic parent (Newberry and Dhaliwal (2001), and Graham (2003)). Thus, the relative tax advantage of issuing debt abroad or at home is a function not only of the corporate, personal tax rates and dividend tax systems within a country, but also the tax treatment of repatriated interest and dividend payments for transfers between countries.

Withholding taxes on dividend payments are usually levied by the subsidiary country on outgoing dividend payments used by the subsidiary to transfer income across borders to the parent company (Huizinga et al. (2008)). This can lead to additional incentive to issue debt through subsidiaries located in countries that have high dividend withholding rates. Since withholding taxes on dividends are in essence an additional corporate tax on income, we conjecture that multinational firms will be more likely to issue debt through subsidiaries located in countries with high withholding tax rates on dividends. 
Withholding taxes on interest payments made to foreign investors can create a taxadvantage for foreign investors to substitute foreign for domestic-issued bonds. Since foreign withholding taxes on interest payments are in addition to domestic personal income taxes, investors may also demand higher rates of return for investing in bonds issued by foreign companies (Kim and Stulz (1992)), creating differences in borrowing costs associated with foreign and domestic debt offerings. We conjecture that multinational corporations will be less likely to issue debt through subsidiaries located in countries characterized by high withholding tax rates on interest.

We create a proxy for withholding tax rates on interest and dividend income using the withholding tax rates reported in PwC's Corporate Taxes a Worldwide Summary for the year prior to the debt issue. Whenever available, we use the maximum withholding rate specified by the bi-lateral treaty between the country in which the foreign subsidiary operates and the country in which the parent is domiciled. If no treaty exists, we use the maximum withholding rate for non-treaty countries. To our knowledge, our paper is the first to exploit detailed world-wide data on both interest and dividend withholding taxes.

\subsection{The Effect of Exemption and Tax-Credit Systems on Multinational Firms' Profits Repatriation}

Taxes levied by the parent country on repatriated profits from foreign subsidiaries vary depending on the domicile country of the parent company. The majority of countries around the world adopt an exemption system (also known as territorial system). Under this system the 
parent country taxes a firm only on profits earned at home. Foreign subsidiaries' profits repatriated as dividends are exempt. United States, United Kingdom, Japan, Ireland, Mexico, Poland, and South Korea adopt instead a tax-credit system (also known as worldwide system). ${ }^{8}$ Under this system, parent countries tax corporate profits earned outside the parent country. If the foreign tax rate is smaller than the domestic corporate tax rate, a firm pays taxes to the foreign country on subsidiary income and then pays the remaining difference $\left(\operatorname{tax}_{\text {domestic }^{-}}\right.$-tax $\left.{ }_{\text {foreign }}\right)$ to the parent country. Such firm is usually referred as "deficit credit" firm. If, instead, the foreign tax rate is larger than the domestic tax rate, a firm pays taxes to the foreign country on subsidiary income and then receives a credit on the difference ( $\operatorname{tax}_{\text {foreign }}$-tax $\left.x_{\text {domestic }}\right)$ by the parent country. Such firm is referred as an "excess credit" firm (Graham (2008)).

It is important to notice that multinational firms are likely to keep foreign subsidiary profits in the foreign country for operational and investing needs. That is especially true for "deficit credit" firms with parents domiciled in tax-credit system countries. Therefore we expect that, in normal circumstances, the prediction advanced in section 2.1 holds independently on the profit repatriation tax system. However, we also expect that, everything else constant, firms with parents domiciled in exemption system countries should be even more likely to issue debt abroad in countries with high corporate tax rates. In our empirical analysis we include a dummy variable equal to one if the parent country adopts an exemption system and the subsidiary country has a corporate tax rate higher than the parent country, and zero otherwise. We call this variable "Exemption System".

\footnotetext{
${ }^{8}$ United Kingdom and Japan shifted from a tax-credit to an exemption system in 2008, outside our sample period.
} 


\section{Sample and Univariate Analysis}

\subsection{Sample Selection}

The sample combines consolidated data from financial statements of the parent company, financial accounting data of subsidiaries when available, various country-level proxies, and debt issuance information for the parent and its domestic and foreign subsidiaries. We compile the sample as follows. From Compustat Global, we collect financial accounting data of non-U.S., non-financial companies with consolidated accounting statements. From Thomson Financial's Security Data Corporation (“SDC”) Global New Issues Database (SDC Global New Issue), we extract public and private debt issues from the international Euro market and syndicated banking markets, foreign bond markets in the U.S. and abroad (e.g., Matadors, Samurai, and Bulldog bonds), and 45 domestic markets. ${ }^{9}$ From SDC we also collect financial statement information pertaining to the issuing subsidiaries when available. ${ }^{10}$ We merge the two samples by parent company name (SDC Global New Issue's data field, "issuer borrower ultimate parent name") and by parent country (SDC Global New Issue's data field, "issuer borrower ultimate parent country"). From this merge, we keep only those issues that have consolidated financial accounting data in the year preceding the debt issue. In addition, we collect data on the location

\footnotetext{
${ }^{9}$ See Henderson et al. (2006) for a thorough description of the international coverage of the SDC Global New Issues database.

${ }^{10}$ SDC provides subsidiary-level accounting data (such as assets, debt, earnings, and revenues) for $19 \%$ of the issuing subsidiaries in our sample.
} 
and number of foreign subsidiaries (both issuing and non-issuing) from LexisNexis Corporate Affiliations when available. ${ }^{11}$

The resulting dataset consists of 8,287 debt issues from 2,437 firms headquartered in 23 countries during the sample period 1995 to 2004. The sample includes firms that issue debt solely through the parent company as well as firms that issue debt through either domestic or foreign subsidiaries, or both. Firms that issue debt through foreign subsidiaries make up at least $15 \%$ of the firms within the sample, $19 \%$ of the total number of issues, and $24 \%$ of the aggregate issuance volume. Among the sample firms covered by Lexis Nexis Corporate Affiliations, about $75 \%$ have at least one subsidiary and about $62 \%$ have at least one foreign subsidiary for an average of 14 subsidiaries for firms.

We note that SDC's coverage of debt market issues differs from country to country. For some countries (such as Australia), SDC collects data from statutory filings to regulatory bodies. For other countries (such as Asian Pacific countries), SDC relies on data from multiple informal sources (e.g., wires, news sources, trade publications, foreign stock exchange filings, and proprietary surveys). Therefore, the sampling of debt issues may be more comprehensive for some countries than others. As argued by Henderson et al. (2006), the noise in the data due to this variation in coverage, if anything, may bias our tests against finding evidence of tax effects on multinational debt location decisions.

SDC does not report intercompany loans. However, our empirical investigation does not necessitate intercompany loan issuance data. In this study we focus our analysis on firms'

\footnotetext{
${ }^{11}$ LexisNexis Corporate Affiliations provides subsidiary data for about $60 \%$ of our sample firms.
} 
decision of where to locate new external debt to either raise new capital or refinance maturing debt. Intercompany loans shift capital (possibly even previously issued debt) between the parent and its subsidiaries and are encompassed in studies which investigate parent and subsidiary leverage levels (i.e., Desai, Foley and Hines (2004)). Since we investigate how international taxation influences the firm's external debt issuing decision at the time of the issuance, intercompany loans are not a primary concern of our study.

Our sample does not include corporations headquartered in the U.S. The inclusion of firms headquartered in the U.S. would result in a sample heavily influenced by the issuing behavior of U.S. parents because the number of debt issues and the quantity of debt issued by U.S. companies during our sample period is larger than that totality of our non-U.S. debt sample. This would limit our ability to interpret our results at an international level. We note, however, that even though we exclude U.S. parent companies, our sample does include debt issuances from subsidiaries located in the U.S. of non-U.S. multinational firms. Therefore our sample includes U.S. country-level data. Our study intends to complement the Desai et al. (2004) study which focuses exclusively on the debt location decision of U.S. parent multinationals.

\subsection{Summary Statistics}

Table 1 provides detailed information on the number of issues and number of issuers by country of origin of the parent company and by issuing entity (e.g., parent versus subsidiary issue). Our data include a significant number of both parent and subsidiary level issues $(4,998$ parent and 3,289 subsidiary). We separate subsidiary level issues into issues from domestic 
subsidiaries and from foreign subsidiaries. We classify all subsidiaries that operate in countries other than the parent country as foreign subsidiaries.

Over the sample period, subsidiaries issued almost $40 \%$ of the total number of debt issues in international marketplaces. Within the sample, Japanese-based firms are heavily represented and account for almost $40 \%$ (42\%) of the total number of debt issues (firms). Among parent companies headquartered in different countries, there is significant variation in the use of subsidiary debt. Parents located in Thailand raise external debt through subsidiaries the least ( $25 \%$ of their total issues) and German firms locate debt in subsidiaries most often (80\% of their total issues).

Within our sample of 3,289 subsidiary debt issues, 1,548 (47\%) are foreign subsidiary debt issues. Similar to our finding above, Japanese firms are heavily represented and account for just over $41 \%$ of the total number of issues from foreign subsidiaries. Among countries, there is significant variation in the use of foreign subsidiary debt. Parents located in Thailand raise external debt through foreign subsidiaries the least (2.6\% of their total subsidiary issues) while Swiss firms locate debt in foreign subsidiaries most often ( $82 \%$ of their total subsidiary issues). We exploit this variation in our multivariate analysis.

The extent to which firms locate debt domestically through a domestic subsidiary or the parent or abroad though foreign subsidiaries is the focal point of this study. However, the reader may be interested in the types of debt contracts that are most likely to be raised through subsidiaries. In the sample, $43 \%$ (42\%) of the total number of issues of straight debt (syndicated 
term loans) are issued by subsidiaries. Convertible debt is most often issued by the parent company. Only $17 \%$ of all convertible debt issues are issued by a subsidiary. ${ }^{12}$

Table 2 presents information on the number of issues and number of issuers by foreign subsidiary country. The foreign subsidiaries that issue debt during our sample period are located in 59 countries. Within the sample, the country in which the largest number of foreign subsidiaries issue debt is the United States (102 subsidiaries issuing debt 547 times). That is companies with parents located outside the U.S. locate debt frequently through U.S. based foreign subsidiaries.

Table 3 presents issue characteristics by issuing entity (i.e., parent, domestic subsidiary, or foreign subsidiary). Within the sample, we find that debt issues by foreign subsidiaries have significantly larger principal than issues by domestic firms (either parent companies or domestic subsidiaries). Larger corporations, which issue larger amounts of debt, might be more likely to own foreign subsidiaries and to issue debt through these subsidiaries. When we control for firm size and other firm characteristics in our multivariate analysis, in fact, we do not find a positive relation between issuing through a foreign subsidiary and issue size.

Debt issued by foreign subsidiaries also has significantly longer dated maturities than debt issued by domestic subsidiaries or parent companies. In an untabulated analysis, we disaggregate issue-specific information by debt type (straight bonds, convertible bonds, and loans). This analysis shows that the difference in issue size and maturity between issues by

\footnotetext{
${ }^{12}$ Our sample consists of 4,666 (56\%) public and private bonds, 1,139 (14\%) convertible bonds, and 2,482 (30\%) term loans. Detailed univariate statistics about the distribution of issues by debt type are available from the authors upon request.
} 
domestic firms and foreign subsidiaries holds for straight and convertible bonds, but not for bank loans.

Table 4 provides issue-level summary statistics for our proxies of tax-based incentives. The table reports means and medians of our tax-based variables by issuer entity. The first column identifies parent-level issues and tabulates the summary statistics using parent country information. The second column identifies debt issued by subsidiaries located in the same country of the parent. In this column, the summary statistics report parent country information. The next two columns identify external debt issued by foreign subsidiaries and provide summary statistics of country-level tax variables for the parent country and foreign subsidiary country, respectively. The last column presents p-values of two-sample t-tests of the mean and Wilcoxon tests of the median for the values presented in the previous two columns.

From these univariate summary statistics, we find preliminary evidence which suggests that differences in tax rates and regimes are related to firms' debt location decision. The pvalues of the differences presented in the last column show that firms that issue debt in foreign subsidiaries have significantly higher gains to leverage measured using either the Debt Tax Gain (a proxy that ignores the impact of personal capital gains taxes) or the Miller Gaines-to-Leverage (a proxy that includes the impact of personal capital gains taxes). The significant difference in “Debt Tax Gain” between foreign subsidiaries' countries and parents' countries appears to be driven by differences in personal income taxes between parent and foreign subsidiary countries rather than by differences in corporate taxes. 
We also find that multinational corporations that locate debt in foreign subsidiaries are on average more likely to have parents domiciled in countries that employ dividend imputation as opposed to the foreign subsidiary (40\% versus $22 \%$ ). This result is consistent with our hypothesis on dividend tax regimes. Since tax systems that employ dividend imputation tend to decrease the relative tax benefit of debt, multinational corporations may preferentially issue debt in countries that do not adopt this type of tax regime.

Table 5 provides issue-level summary statistics of various firm-level attributes that may be related to a firm's debt location decision. We measure all firm-level controls using parentlevel information available in the year preceding the debt issue. The data indicate that on a consolidated accounting basis, multinational corporations that borrow through foreign subsidiaries tend to be significantly larger and more levered, to have lower asset tangibility, lower effective tax rates, and longer asset maturity. It may be the case that both the parent and foreign subsidiaries of larger firms are more recognizable to international investors. In this case, larger multinational corporations face lower costs of asymmetric information when issuing through foreign subsidiaries and thus face lower costs of borrowing through foreign subsidiaries in certain marketplaces. ${ }^{13}$ We note that our classification of parent and domestic subsidiary issues includes multinational firms that issue domestically. The presence of multinational firms in the issue-level summary statistics for parent and domestic subsidiaries in Table 5 biases the

\footnotetext{
${ }^{13}$ Consider CEMEX. CEMEX is headquartered in Mexico, but also operates foreign subsidiaries in the U.S. Comparing the cost of debt capital across both markets, CEMEX may decide to issue debt in the U.S. In order to minimize the cost of debt finance, CEMEX borrows through its U.S. affiliate so that the affiliate can pledge capital that can be seized in the event of default by U.S. creditors. Since CEMEX is large and well recognized by U.S. investors, they are willing to borrow through the affiliate.
} 
data against finding a significant difference in firm-level attributes between domestic and foreign issues.

Table 6 presents correlations among the variables used in the multivariate analysis. As expected, firm size is highly correlated with issue size, leverage, and the number of foreign subsidiaries. Among the tax variables, Relative Debt Tax Gain is highly negatively correlated with Relative Personal Taxes while Relative Miller Gains-to-Leverage is highly positively correlated with Relative Capital Gain Tax because of the way these variables are constructed. Relative Debt Tax Gain is also highly correlated with Relative Miller Gains-to-Leverage. Even though in our main regressions we use Relative Debt Tax Gain, in untabulated regressions we substitute it with Relative Miller Gains-to-Leverage obtaining very similar results.

\section{Multivariate Analysis}

\subsection{Multivariate Analysis of the Decision of Where to Locate Debt}

In Table 7, we present a logistic analysis of the corporate debt location choice. The dependent variable in the logistic regression is zero if the debt is issued by either the parent or a domestic subsidiary and one if it is issued by a foreign subsidiary. The right hand side variables include the Relative Debt Tax Gain, Relative Dividend Imputation, Relative Dividend Relief and Exemption System variables, as well as various issue-level, firm-level, and country-level controls (described in the Appendix). We cannot include our Interest and Dividend Withholding 
Tax variables in these regressions because they predict issues by foreign subsidiary perfectly. ${ }^{14}$ Finally, in each regression model, we also include year and firm fixed effects.

The first column of Table 7 examines tax-based incentives of debt location in multinational corporations. Consistent with Hodder and Senbet (1990), we find that firms are more likely to locate debt in a foreign subsidiary when the foreign subsidiary operates in a tax environment that provides for greater tax advantage of debt as measured by the Relative Debt Tax Gain variable. Desai et al. (2004) and Huizinga et al. (2008) also find multinational debt location choice is affected by taxes. However, they consider only corporate taxes. Our measure, Relative Debt Tax Gain, includes the impact of personal taxes on income as well corporate taxes and thus provides more comprehensive support for tax-based motives in debt location.

The coefficient of the Relative Dividend Imputation is negative and significant. This result suggests that multinational firms headquartered in countries with a dividend imputation system are more likely to issue debt through a subsidiary located in a country without dividend imputation taxation where the after-tax cost of debt is lower relative to equity. The Exemption System indicator variable is positive and significant suggesting, consistent with our hypothesis, that corporations with parents in countries that adopt the exemption system for repatriated profits are more likely to issue debt through foreign subsidiary in countries with higher corporate taxes, everything else constant.

\footnotetext{
${ }^{14}$ When the dependent variable is zero (domestic issues), the withholding variables are always equal to zero; and when the dependent variable is one (foreign issues), the withholding variables are always equal or larger than zero. We include the withholding variables in the regressions presented in Table 7.
} 
In the second column of Table 7, we expand our logistic regression to control for the possible influence that issue-level and firm-level characteristics may have on the decision of where to locate debt. Consistent with Table 5, the coefficients of our firm-level characteristics show that larger and more profitable firms are more likely to issue debt through a foreign subsidiary. Companies with more tangible assets are more likely to issue debt domestically. Domestic issues are usually larger and convertible debt is more likely to be issued domestically while loans are more likely to be used by foreign subsidiaries. Even controlling for issue-level and firm-level variables, we still find that multinational firms are more likely to locate debt in a foreign subsidiary when the foreign subsidiary operates in a tax environment that provides for greater tax advantage of debt.

In the third column of Table 7, we also include our subsidiary-level variables. In order to include subsidiary-level data, which is available only for one fifth of our sample, we apply a method often used to avoid losing observations with missing financial statement variables (e.g., Palia (2001) and Fama and French (2002)). This method consists of setting the missing subsidiary-level variable values to zero and introducing indicator variables that are set to unity for the missing observations. With this approach we are able to exploit the statistical power offered by our overall sample for most of our variables while analyzing the effect of subsidiarylevel data when available.

The results of this regression show that companies are more likely to issue debt through a foreign subsidiary when the subsidiary has a higher profitability that the overall company, as indicated by the coefficient of the Sub/Parent ROA variable. Considering that companies that 
repatriate foreign profits might face double taxation (the foreign country taxes and withholding taxes on dividends in absence of a bi-lateral tax treaty), it is in the interest of these firms to shield high foreign subsidiary profits with more debt in comparison to domestic subsidiary profits. Overall, the results of this column show that, even controlling for subsidiary-level data, the significance of our tax variable, Relative Debt Tax Gain, persist.

In addition to tax considerations and firm-specific characteristics, a multinational corporation's decision of where to locate debt may also be related to differences in legal protection (La Porta et al. (1997), La Porta et al. (1998)), credit market depth (Titman (2002)), and exchange rate risk (Shapiro (1984)). While not the focus of this study, we control for these factors in our multivariate analysis.

As a proxy for the legal regime in a country, we use country-level dummies indicating whether a country's legal system is based upon common law. We identify common law countries in our dataset following La Porta et al. (1997). To examine rule of law, the second determinant of the legal protection provided by a country, we use the rule of law indicator created by La Porta et al. (1998). To proxy for the credit market depth, we measure the ratio of a country's net deposits to gross domestic product (“GDP") as reported by the International Financial Statistics ("IFS"). Similar to Allayannis et al. (2003), we measure exchange rate risk by calculating the ratio of the short-term lending rate in the subsidiary country to the short-term 
lending rate in the parent country as provided by the World Bank. ${ }^{15}$ Additionally, as a

robustness check, we use sovereign yield spread as an alternative exchange rate risk measure.

In order to analyze these factors in our multivariate analysis, we create relative variables

for each proxy by dividing its value in the subsidiary country by its value in the parent country.

The resulting variables are Relative Common Law, Relative Rule of Law, Relative Deposits /

GDP, and Relative Short Term Interest. We present a detailed description of these variables in

the Appendix.

The fourth column of Table 7 presents the results of a regression in which we control for the effects of these variables on the debt location decision of multinational corporations in addition to the variables presented in the other two columns. Even controlling for these country variables, our tax variables maintain their statistical significance.

Both the relative common law and rule of law variables are positive and significant. ${ }^{16}$ Parents located in civil (common) law countries are more (less) likely to issue debt through subsidiaries located in common (civil) law countries. Moreover, parent located in countries with poor (good) law enforcement and less (more) developed debt market are more likely to issue debt internationally (domestically). These results complement those of Desai et al. (2004), who

\footnotetext{
${ }^{15}$ It might be argued that a short-lending rate variable could also proxy for debt market timing. Because of interest rate parity considerations, empirical proxies of currency exchange differentials might also be viewed as proxies of international interest rate differentials. While we do not exclude interest rate market timing when interpreting our short-term interest variable, previous studies have shown that exchange rate risk is a stronger driver of foreign debt location. Henderson et al. (2006) do not find significant empirical support for the hypothesis that firms issue debt abroad to take advantage of lower foreign interest rates. Conversely. Bartram et al. (2010) find that financial currency hedging with foreign debt is one of the main methods adopted by firms to decrease exchange rate exposure. ${ }^{16}$ The variance inflation factors of the common law and rule of law variables are less than two, establishing an absence of multicollinearity between these two variables.
} 
find that foreign subsidiaries domiciled in poor creditor protection countries issue less external debt and borrow more internally.

The coefficient of the Relative Short Term Interest variable suggests that multinational companies are more likely to issue debt in countries with high exchange rate risk, measured by the relative subsidiary-to-parent country short-term interest rate. This result may indicate that foreign debt issuance is used as an exchange rate risk hedging strategy. Multinational firms that generate a significant amount of operating cash flows from foreign operations may attempt to hedge the exchange rate risk of these cash inflows by issuing foreign currency debt through their foreign subsidiaries (Shapiro (1984), Bartram et al. (2010)). ${ }^{17}$ The sign of the coefficient does not support, instead, the conjecture that firms time the debt market by issuing debt in countries with lower interest rates.

In the last column of Table 7 we report a logistic regression that includes the number of foreign subsidiaries owned by our sample firms. The number of foreign subsidiaries is a proxy for investing opportunities in foreign countries. Corporations are likely to match investing opportunities with local financing, and therefore we expect that firms with a larger number of foreign subsidiaries will issue more foreign debt. Consistent with this conjecture the number of foreign subsidiary variable is positive and significant. The inclusion of this variable does not change the sign and significance of the tax and country variables with the exclusion of the relative Dividend Relief variable. In this specification the Dividend Relief variable is negative and significant consistent with our hypothesis on dividend imputation and relief systems.

\footnotetext{
${ }^{17}$ As further explained in Section 5, we replicate our regressions with a relative sovereign yield spread variable as an alternative proxy for exchange rate risk. Our results do not significantly change.
} 
We also assess the economic significance of the tax-related variables on a firm's debt location choice for the specification presented in the last column. An increase in the Relative Debt Tax Gain variable from its $25^{\text {th }}$ to its $75^{\text {th }}$ percentile, holding all the other variables at their median values, increases the probability of issuing debt through a foreign subsidiary by $7.15 \%$. If a subsidiary is located in a country with dividend imputation (dividend relief) while the parent is headquartered in a country with a classical dividend tax system, the probability of issuing debt though the foreign subsidiary is $16.11 \%(3.32 \%)$ lower. Companies with parents domiciled in countries which adopt a tax exemption system are $18.23 \%$ more likely to issue debt through foreign subsidiaries when the foreign country has a higher corporate tax rate.

\subsection{Multivariate Analysis of the Proportion of Debt Located in Foreign Subsidiaries}

Table 7 presents the results of Tobit regressions. The dependent variable in the regressions is the ratio of the amount of debt issued by all foreign subsidiaries of a company located in a specific country to the total amount of debt issued by the multinational firm in a fiscal year. Since companies issue debt only in a limited set of foreign countries, the dependent variable is left-censored at zero. We estimate a Tobit regression to account for the censoring of the dependent variable.

While the logistic regressions presented in Table 7 examine the binary choice between issuing debt domestically or abroad, the Tobit regressions of Table 8 examine the corporate choice concerning the allocation of total debt issued each year across each foreign country where 
subsidiaries are located. ${ }^{18}$ Unlike in our logistic analysis, here we are able examine the impact of withholding taxes on the allocation choice of debt issued abroad. This is possible because the regression examines the allocation of debt issued in foreign countries rather than the decision of whether to issue domestically or internationally.

The first column of Table 8 examines tax-based incentives of debt location in multinational corporations. The positive coefficient on Debt Tax Gain is consistent with the view that firms are more likely to issue larger quantities of debt through a subsidiary in countries where personal and corporate taxes provide a higher tax advantage of debt. The relative dividend imputation and dividend relief variables are negative and significant. Multinational corporations issue larger quantities of debt through subsidiaries located in countries without dividend imputation of dividend relief rules where the after-tax cost of debt is relatively lower than the cost of equity.

Consistent with our hypothesis that multinational corporations might be less likely to issue debt through subsidiaries located in countries characterized by high withholding tax rates on interest, the interest withholding variable is negative and significant. Multinational firms issue larger quantities of debt in foreign countries with low or non-existing interest withholding taxes. This result is consistent with the hypothesis that, since foreign withholding taxes on interest payments are in addition to domestic personal income taxes, investors may demand higher rates of return for investing in bonds issued by foreign companies, creating differences in

\footnotetext{
${ }^{18}$ We estimate these regressions for the sample of firms covered by Lexis Nexis Corporate Affiliations for which we have information on the total number of subsidiaries (independently on debt issuance) in each foreign country for each corporation.
} 
borrowing costs associated with foreign and domestic debt offerings. The coefficient of the Exemption System variable show that firms with parents domiciled in countries with a tax exemption system are issuing a larger quantity of debt through foreign subsidiaries domiciled in countries with higher corporate tax rates.

As in Table 7, in the second column of Table 8 we expand our Tobit regression to control for the possible influence of issue-level characteristics and firm-level characteristics that may impact the corporate debt location decision. The results for the control variables are consistent with those presented in the first column of Table 7. The tax-based variables significant in the first column also maintain their significance when controlling for firm and issue-level variables. However, different from the results in the first column, the dividend withholding variable is positive and significant. This result is consistent with the hypothesis that firms issue larger amount of debt through foreign subsidiaries located in countries with higher withholding taxes on dividends. The subsidiary country can levy taxes on outgoing dividend payments used by the subsidiary to transfer income to the parent company, leading to additional incentives to issue debt through subsidiaries located in high dividend withholding rate countries.

Huizinga et al. (2008) do not find that dividend withholding rates have a significant effect on debt location decisions by multinational corporations. The difference between the results of our study and those of Huizinga et al. (2008) might derive from the difference in the two samples. While Huizinga et al. (2008) limit their analysis to European companies, we extend our analysis to all non-U.S. firms. Since our sample also comprises non-European firms, our 
dividend withholding variable has a larger variability across countries, which, in turn, increases the power of our test.

In addition to the tax-based variables and the firm and issue-level controls, the third column of Table 8 also controls for the effects of legal and institutional variables on the debt location decision of multinational corporations. The relative rule of law variable is positive and significant, suggesting that multinational corporations issue a larger quantity of debt in countries with better rule of law. The coefficients for the proxies for credit market depth and exchange rate risk (Relative Deposits / GDP and Relative Short Term Interest, respectively) are not significant. These results, in combination with the significance of these variables in Table 7 , suggest that even though multinational firms are more likely to issue debt in foreign countries where debt markets are more developed and in countries with higher risk of currency depreciation, the relative quantity of debt issued through subsidiaries in different foreign countries is not significantly affected by the specific debt market development and exchange risk of each single country.

The last column of Table 8 presents the results of a regression that also includes the number of subsidiaries each firm has in each foreign country. The coefficient of this variable is positive and significant, offering evidence that companies issue larger quantity of debt in countries with a larger number of subsidiaries where investing opportunities are more numerous. For the remaining variables, the results of this regression are consistent with those presented in the other columns. 


\section{Robustness Tests}

\subsection{Exclusion of Japanese Multinational Corporations and U.S. Subsidiaries}

As shown in Table 1, out of the 4,998 issues by parent companies in our sample, 2,341 $(46.8 \%)$ are from Japan. To verify that our results are not exclusively driven by Japanese corporations, in Table 9 we replicate the analysis presented in Table 7 excluding parent companies domiciled in Japan. All the coefficients of the tax-related variables maintain the same sign and significance as in Table 7. Overall, these results show that our results are not driven by Japanese corporations.

As Japanese corporations represent a large portion of the parent sample, U.S. subsidiaries of non-U.S. companies corresponds to a sizeable part of all issuing foreign subsidiaries (29\%). When we replicate the analysis of Table 7 excluding U.S. subsidiaries of non-U.S. corporations, we find that the tax-related results of this study are not driven by U.S.-located foreign subsidiaries.

\subsection{Alternative Proxies}

The multivariate analyses presented in Tables 7 and 8 comprise a limited selection of proxies for country legal protection, debt market development, and exchange rate risk. We check the robustness of our results by estimating similar regressions with different proxies for these variables. 
The level of corruption in a country provides a proxy for the threat of expropriation of investor rights and the integrity of the legal system. Therefore, corruption can be used as an alternative proxy for rule of law (see, for example, Fan et al. (2008)). When we estimate our regressions substituting the rule of law variable with the corruption index provided by Transparency International, our tax-related results do not change. Another proxy for rule of law and legal enforcement is the legality index created by Berkowitz et al. (2003). This index is derived by the summary statistic from a principal component analysis of five measures of legal enforcement: 1) effectiveness of the judiciary, 2) rule of law, 3) risk of contract repudiation, 4) absence of corruption, and 5) risk of expropriation. Our multivariate results are robust to the substitution of rule of law with the legality index.

In Tables 7 and 8, the ratio of a country's net deposits to GDP proxies for the depth and development of debt markets in different countries. An alternative proxy for debt market development is the ratio of aggregate debt (sum of bank debt of the private sector and outstanding non-financial bonds) to GDP (see, for example, La Porta et al. (1997)). We reestimate our regressions with aggregate debt to GDP instead of net deposits to GDP. Again, our tax-related results are robust to this change in the debt market development proxy.

Finally, in our main regressions, we measure exchange rate risk by calculating the ratio of the short-term lending rate in the subsidiary country to the short-term lending rate in the parent country as provided by the World Bank. A possible alternative to this variable is the sovereign yield spread proxied by the country credit rating provided by Institutional Investor. Our 
multivariate results are robust to the substitution of lending rate differential with country credit rating differential.

\section{Conclusions}

This paper examines the external debt financing choices of multinational firms by examining the incremental debt decision of companies headquartered in 23 countries spanning ten years (from 1995 to 2004). This study benefits from the broadest international dataset and the most complete set of tax-related variables and institutional controls used in the international capital structure literature. Our empirical analysis allows us to provide new powerful tests of the ability of multinational firms to arbitrage differences in international tax rates, while controlling for firm-specific and country-level factors, such as the level of debt market development, legal regimes, and exchange rate risk.

Unlike previous studies on international corporate debt decisions (e.g., Desai et al. (2004) and Huizinga et al. (2008)), we examine the firm's incremental debt issuance decision. Our novel approach in the context of multinational corporate structure decisions links the borrowing decision of the firm with variables measured just prior to the debt issuance, allowing analysis of the effect of time-variation in tax factors on the debt location choice. Moreover, this approach provides more power to identify effects that are determined at the margin, such as taxes.

Our results provide strong support for tax-based theories of debt location. Consistent with our predictions, we find that parent companies that operate in favorable (unfavorable) tax environments for corporate debt (measured by a variant of the Miller (1977) gains-to-leverage 
ratio) are less (more) likely to issue through foreign subsidiaries located in countries with tax rates less (more) favorable for corporate debt. We also show that parent companies domiciled in countries that employ dividend imputation or dividend relief are more likely to locate debt through foreign subsidiaries in countries that employ the classical dividend tax system.

Moreover, we show that corporations with parents domiciled in countries with a tax exemption system on repatriated profits are more likely to issue debt through foreign subsidiaries in high corporate tax countries than companies with parents domiciled in countries with a tax credit system. Finally, we find that multinational corporations issue larger quantities of debt through subsidiaries located in countries that have low withholding taxes on interest income and high withholding taxes on dividends with the country where the parent company resides.

Our results of the tax effects on international corporate debt location decisions are robust to issue and firm-level characteristics, proxies for the development of debt markets, exchange rate risk, and differences in legal regimes. Overall our paper presents strong evidence that a wide array of tax-based incentives has a significant influence on multinational firms' debt location choice. 


\section{Acknowledgments}

We thank Sean Cleary, Viet Anh Dang, Michael Dewally, Leslie Eustice, John Howe, Brandon Julio, Sarah Peck and seminar participants at University of Missouri, Marquette University, the 2008 Annual Meeting of the Financial Management Association, and the 2009 European Conference of the Financial Management Association for helpful comments and suggestions. 


\section{References}

Allayannis, G., Brown, G.W., Klapper, L.F., 2003. Capital structure and financial risk: Evidence from foreign debt use in East Asia. J. Financ. 58, 2667-2709.

Arena, M.P., 2010. The corporate choice between public debt, bank loans, traditional private debt placements, and 144A debt issues. Rev. Quant. Financ. Account. forthcoming

Arena, M.P., Howe, J.S., 2009. Takeover exposure, agency, and the choice between private and public debt. J. Financ. Res. 32, 199-230.

Bartram, S.M., Brown, G.W., Minton, B.A., 2010. Resolving the exposure puzzle: The many facets of exchange rate exposure. J. Financ. Econ. 95, 148-173.

Berkowitz, D., Pistor, K., Richard, J.-F., 2003. Economic development, legality, and the transplant effect. Eur. Econ. Rev. 47, 165-195.

Booth, L., Aivazian, V., Demirguc-Kunt, A., Maksimovic, V., 2001. Capital structures in developing countries. J. Financ. 56, 87-130.

Chowdhry, B., Coval, J.D., 1998. Internal financing of multinational subsidiaries: Debt vs. equity. J. Corp. Financ. 4, 87-106.

Chowdhry, B., Nanda, V., 1994. Internal financing of multinational subsidiaries: Parent debt vs. external debt. J. Corp. Financ. 1, 259-281.

Demirguc-Kunt, A., Maksimovic, V., 1988. Law, finance, and firm growth J. Financ. 53, 21072137.

Denis, D.J., Mihov, V.T., 2003. The choice among bank debt, non-bank private debt and public debt: evidence from new corporate borrowings. J. Financ. Econ. 70, 3-28.

Desai, M.A., Foley, C.F., Hines, J.R.J., 2004. A multinational perspective on capital structure and internal capital markets. J. Financ. 59, 2451-2486.

Fan, J.P.H., Titman, S., Twite, G., 2008. An international comparison of capital structure and debt maturity choices. Working Paper.

Graham, J.R., 1996. Proxies for the marginal tax rate. J. Financ. Econ. 41, 41-74.

Graham, J.R., 2003. Taxes and corporate finance: A review. Rev. Financ. Stud. 16, 1074-1129. 
Graham, J.R., 2008. Taxes and Corporate Finance. In: Eckbo BE (ed.) Handbook of Corporate Finance. North-Holland, pp. 59-133.

Harvey, C.R., Lins, K.V., Roper, A.H., 2004. The effect of capital structure when expected agency costs are extreme. J. Financ. Econ. 74, 3-30.

Henderson, B.J., Jegadeesh, N., Weisbach, M.S., 2006. World markets for raising new capital. J. Financ. Econ. 82, 63-101.

Hodder, J.E., Senbet, L.W., 1990. International capital structure equilibrium. J. Financ. 45, 14951516.

Huizinga, H., Laeven, L., Nicodeme, G., 2008. Capital structure and international debt shifting. J. Financ. Econ. 88, 80-118.

Kim, Y.-C., Stulz, R.M., 1992. Is there a global market for convertible bonds. J. Bus. 65, 75-91.

La Porta, R., Lopez-de-Silanes, F., Shleifer, A., Vishny, R., 1997. Legal determinants of external finance. J. Financ. 52, 1131-1150.

La Porta, R., Lopez-de-Silanes, F., Shleifer, A., Vishny, R., 1998. Law and finance. J. Pol. Econ. $106,1113-1155$.

MacKie-Mason, J., 1990. Do taxes affect corporate financing decisions. J. Financ. 45, 14711493.

Miller, M.H., 1977. Debt and Taxes. J. Financ. 32, 261-275.

Newberry, K.J., 1998. Foreign tax credit limitations and capital structure decisions. J. Account. Res. 36, 157-166.

Newberry, K.J., Dhaliwal, D.S., 2001. Cross-jurisdictional income shifting by U.S. multinationals: Evidence from international bond offerings. J. Account. Res. 39, 643-662.

Noe, T.H., 2000. Creditor rights and multinational capital structure. Working Paper, Tulane University.

Palia, D., 2001. The endogeneity of managerial compensation in firm valuation: a solution. Rev. Financ. Stud. 14, 735-764.

Shapiro, A.C., 1984. Currency risk and relative price risk. J. Financ. Quant. Anal. 19, 365-373. 
Titman, S., 2002. The Modigliani and Miller Theorem and Market Efficiency. Financ. Manag. 31, 101-115. 


\section{Appendix \\ Variable Definitions and Sources}

\begin{tabular}{ll}
\hline Variable & \multicolumn{1}{c}{ Definition } \\
\hline Aggregate Debt/GDP & $\begin{array}{l}\text { Ratio of the sum of bank debt of the private sector and outstanding non- } \\
\text { financial bonds to GDP. } \\
\text { Gsset Maturity }\end{array}$ \\
Asset Tangibility & $\begin{array}{l}\text { Fraction of fixed assets calculated as gross plant, property, and equipment } \\
\text { divided by total assets. }\end{array}$ \\
Capital Gain Tax Rate & $\begin{array}{l}\text { Country capital gain tax rate. } \\
\text { Common Law }\end{array}$ \\
Convertible & $\begin{array}{l}\text { Indicator variable equal to one if the subsidiary country is a common law } \\
\text { country as defined by La Porta et al. (1998) and zero otherwise. }\end{array}$ \\
Indicator variable equal to one when the issue is convertible debt. \\
Creditor Right
\end{tabular}

Debt Tax Gain

Deposits / GDP

Dividend Imputation System

Dividend Relief System
Tax advantage of debt: $1-((1-\mathrm{Tc}) /(1-\mathrm{Tp}))$ where Tc is the corporate tax rate, and $\mathrm{Tp}$ is the personal tax rate on interest income.

Ratio of the country's deposits to GDP.

An indicator equal to one if the country adopts the dividend imputation tax system, zero otherwise.

An indicator equal to one if the country adopts the dividend relief tax system, zero otherwise.

\section{Source}

International Financial Statistics, International Monetary Fund

Global Vantage

Global Vantage

Price Waterhouse's Taxes a Worldwide Summary

La Porta et al. (1998)

SDC

PwC's Corporate Taxes a Worldwide Summary and Individual Taxes a Worldwide Summary

La Porta et al. (1997)

PwC's Corporate Taxes a Worldwide Summary and Individual Taxes a Worldwide Summary

International Financial Statistics, International Monetary Fund

Fan, Titman, and Twite (2003)

Fan, Titman, and Twite (2003) 
Dividend Withholding Tax Rate

Effective Tax Rate

Exemption System

Income Tax Rate

Interest Coverage

Interest Withholding Tax Rate

Leverage

Loan

Log Assets

Log Maturity

Log Principal

Market to Book

Miller Gains-to-Leverage

$N$ Foreign Subs

$N$ Subs in Country
Dividend withholding tax rate between the subsidiary country and the parent country. Whenever available, we use the maximum withholding rate specified by the treaty in the country in which the non-resident subsidiary operates. If no treaty exists, we use the maximum withholding rate for non-treaty countries.

Corporate taxes paid divided by taxable income.

An indicator equal to one if the parent country adopts an exemption system and the subsidiary country has a corporate tax rate higher than the parent country, and zero otherwise.

Country personal income tax rate.

Interest coverage calculated as earnings before interest, taxes, amortization and depreciation divided by interest expense.

Interest withholding tax rate between the subsidiary country and the parent country. Whenever available, we use the maximum withholding rate specified by the treaty in the country in which the non-resident subsidiary operates. If no treaty exists, we use the maximum withholding rate for non-treaty countries.

Total debt divided by total assets.

Indicator variable equal to one when the issue is a bank loan.

Natural logarithm of total assets.

Natural logarithm of debt maturity expressed in years. For firms that issue multiple contracts in a single year, we calculate a duration weighted maturity using the individual debt proceeds amount as the weights.

Natural logarithm of the debt issue dollar amount. For firms that issue multiple contracts in a single year, we aggregate the proceeds amount across similar contracts.

Market capitalization divided by the book value of equity.

Miller (1977) gains-to-leverage formula. The Miller (1977) gains-toleverage formula is: $1-((1-\mathrm{Tc})(1-\mathrm{Te}) /(1-\mathrm{Tp}))$ where Tc is the corporate tax rate, $\mathrm{Te}$ is the tax rate on capital gains, and $\mathrm{Tp}$ is the tax rate on interest income.

Number of foreign subsidiaries owned by each corporation

Number of subsidiaries owned by a corporation in each foreign country
PwC's Corporate Taxes a Worldwide Summary and Individual Taxes a Worldwide Summary

Global Vantage

PwC's Corporate Taxes a Worldwide Summary and

PwC's Individual Taxes a Worldwide Summary

Global Vantage

PwC's Corporate Taxes a Worldwide Summary and Individual Taxes a Worldwide Summary

Global Vantage

SDC

Global Vantage

SDC

SDC

Global Vantage

PwC's Corporate Taxes a Worldwide Summary and Individual Taxes a Worldwide Summary

LexisNexis Corporate Affiliations

LexisNexis Corporate Affiliations 
Relative Common Law

Relative Creditor Rights

Relative Debt Tax Gain

Relative Deposits / GDP

Relative Dividend Imputation

Relative Dividend Relief

Relative Rule of Law

Relative Short Term Interest

$R O A$

ROA St. Dev

Rule of Law

Short-Term Interest Rate
Indicator variable equal to one if the subsidiary country is a common law country and the parent country is not a common law country, zero if either or neither country is a common law country, and minus one of the subsidiary country is not a common law country and the parent country is a common law country.

Indicator variable equal to one if the subsidiary country has more creditor rights than the parent country, equal to zero if both countries have the same number of creditor rights, and equal to minus one if the subsidiary country has less creditor rights than the parent country.

Difference between the Debt Tax Gain variable for the subsidiary country and for the parent country.

Ratio of the subsidiary country's deposits to GDP divided by the ratio of the parent country's deposits to GDP.

An indicator equal to one if the subsidiary country adopts the dividend imputation tax system and the parent country does not, equal to zero if either or neither country adopts the dividend imputation tax system, and equal to minus one if the subsidiary country does not adopt the dividend imputation tax system but the parent country does.

An indicator equal to one if the subsidiary country adopts the dividend imputation tax system and the parent country does not, equal to zero if either or neither countries adopt the dividend imputation tax system, and equal to minus one if the subisidiary country does not adopt the dividend imputation tax system but the parent country does.

Indicator variable equal to one if the subsidiary country has a higher rule of law score than the parent country, zero if both countries have the same rule of law score, and minus one if the subsidiary country has a lower rule of law score than the parent country.

Ratio of the short-term lending rate in the subsidiary country to the shortterm lending rate in the parent country.

EBITDA divided by total assets.

Standard deviation of EBITDA divided by total assets for the previous 10 years (or for all available years if fewer than 10).

Assessment of the law and order tradition in the country. Average of the months of April and October of the monthly index between 1982 and 1995. Scale from 0 to 10, with lower scores for less tradition for law and order.

Country short-term lending rate.
La Porta et al. (1998)

La Porta et al. (1997)

PwC's Corporate Taxes a Worldwide Summary and Individual Taxes a Worldwide Summary

International Financial Statistics, International Monetary Fund

Fan, Titman, and Twite (2003)

Fan, Titman, and Twite (2003)

International Country Risk Guide

World Development Indicators, World Bank

Global Vantage

Global Vantage

International Country Risk Guide

World Development Indicators, World Bank 
Sub/Parent Leverage

Sub/Parent Loss

Sub/Parent ROA

Total Assets

Total Sales
Ratio of issuing (domestic or foreign) subsidiary leverage to parent leverage. If the issuing entity is the parent, the variable assumes the value of one.

Indicator variable equal to one when the issuing (domestic or foreign) subsidiary posts a loss in the year preceding the issue while the parent posts positive net income, equal to minus one when the issuing subsidiary posts positive net income in the year preceding the issue while the parent posts a loss, and equal to zero when both subsidiary and parent post net income or a loss. If the issuing entity is the parent, the variable assumes the value of zero.

Ratio of issuing (domestic or foreign) subsidiary return on assets to parent return on assets. If the issuing entity is the parent, the variable assumes the value of one. Return on assets is calculated as EBITDA over assets.

Total assets of the firm expressed in millions of dollars calculated at the end of the fiscal year preceding the debt issue.

Total sales of the firm expressed in millions of dollars calculated at the end of the fiscal year preceding the debt issue.
SDC

SDC

SDC

Global Vantage

Global Vantage 
Table 1

Descriptive Statistics by Parent Country and Issuing Entity

\begin{tabular}{|c|c|c|c|c|c|c|c|c|}
\hline \multirow[b]{2}{*}{ Japan } & \multicolumn{2}{|c|}{ All Issuers } & \multicolumn{2}{|c|}{ Headquarters } & \multicolumn{2}{|c|}{$\begin{array}{l}\text { Domestic } \\
\text { Subsidiary }\end{array}$} & \multicolumn{2}{|c|}{$\begin{array}{c}\text { Foreign } \\
\text { Subsidiary }\end{array}$} \\
\hline & 3384 & (1023) & 2341 & (959) & 404 & (137) & 639 & $(77)$ \\
\hline United Kingdom & 743 & $(264)$ & 486 & (225) & 158 & $(71)$ & 99 & $(42)$ \\
\hline South Korea & 594 & (81) & 341 & (71) & 197 & $(30)$ & 56 & (15) \\
\hline Canada & 530 & $(177)$ & 358 & $(162)$ & 123 & $(32)$ & 49 & (23) \\
\hline Germany & 410 & (62) & 85 & (47) & 72 & (19) & 253 & (30) \\
\hline France & 357 & (95) & 203 & (84) & 108 & (22) & 46 & $(20)$ \\
\hline Taiwan & 335 & (77) & 201 & (75) & 101 & $(22)$ & 33 & (15) \\
\hline Australia & 222 & (83) & 129 & (64) & 59 & $(26)$ & 34 & (16) \\
\hline Hong Kong & 222 & (86) & 82 & (49) & 101 & $(45)$ & 39 & (12) \\
\hline Switzerland & 190 & (45) & 66 & (34) & 22 & (11) & 102 & $(20)$ \\
\hline Spain & 157 & (34) & 49 & (26) & 35 & (13) & 73 & $(10)$ \\
\hline India & 149 & (41) & 94 & (37) & 48 & (9) & 7 & (4) \\
\hline Thailand & 149 & (51) & 111 & (47) & 37 & $(15)$ & 1 & (1) \\
\hline Mexico & 143 & (35) & 90 & (31) & 49 & (14) & 4 & (2) \\
\hline Netherlands & 134 & (43) & 80 & (32) & 23 & (13) & 31 & (17) \\
\hline Singapore & 126 & (43) & 55 & $(31)$ & 49 & (14) & 22 & (6) \\
\hline Indonesia & 89 & (43) & 49 & (35) & 32 & (11) & 8 & (6) \\
\hline Brazil & 87 & (28) & 53 & (25) & 31 & (13) & 3 & (2) \\
\hline Malaysia & 81 & (51) & 45 & (33) & 28 & (16) & 8 & (7) \\
\hline Sweden & 71 & (16) & 25 & (12) & 30 & (8) & 16 & (4) \\
\hline Norway & 45 & (23) & 24 & (17) & 12 & (9) & 9 & (3) \\
\hline Italy & 41 & (19) & 15 & (14) & 11 & (6) & 15 & (4) \\
\hline Finland & 28 & $(17)$ & 16 & $(12)$ & 11 & $(5)$ & 1 & $(1)$ \\
\hline Total & 8287 & (2437) & 4998 & (2122) & 1741 & (561) & 1548 & (338) \\
\hline
\end{tabular}

This table provides information on the number of issues and number of issuers (in parenthesis) by country of origin of the parent company and by issuing entity (e.g., parent versus domestic and foreign subsidiary issues). 
Table 2

Descriptive Statistics by Foreign Subsidiary Country

\begin{tabular}{|c|c|c|}
\hline & \multicolumn{2}{|c|}{ Foreign Subsidiary } \\
\hline United States & $\begin{array}{c}\text { Issues } \\
547\end{array}$ & $\begin{array}{c}\text { Issuers } \\
(102)\end{array}$ \\
\hline Netherlands & 249 & (44) \\
\hline United Kingdom & 179 & (20) \\
\hline Australia & 57 & (16) \\
\hline Cayman Islands & 52 & (15) \\
\hline Singapore & 33 & (5) \\
\hline Hong Kong & 32 & (10) \\
\hline Canada & 29 & (6) \\
\hline Luxembourg & 26 & (10) \\
\hline Brazil & 22 & (3) \\
\hline Indonesia & 21 & $(5)$ \\
\hline China & 20 & (9) \\
\hline Belgium & 19 & (3) \\
\hline France & 18 & (6) \\
\hline Thailand & 18 & (6) \\
\hline Chile & 18 & (7) \\
\hline Malaysia & 16 & (4) \\
\hline Japan & 15 & (4) \\
\hline Mexico & 12 & (3) \\
\hline Jersey & 12 & (6) \\
\hline Bermuda & 12 & (2) \\
\hline Germany & 11 & (3) \\
\hline South Korea & 9 & (2) \\
\hline Spain & 9 & (8) \\
\hline Others & 112 & (39) \\
\hline Total & 1548 & $(338)$ \\
\hline
\end{tabular}

This table provides information on the number of foreign-subsidiary issues and issuers (in parenthesis) by country of the foreign subsidiary. 
Table 3

Univariate Analysis - Issue Characteristics

\begin{tabular}{|c|c|c|c|c|c|}
\hline & & Parent & Dom. Sub. & For. Sub. & p-values \\
\hline \multirow{3}{*}{ Principal (\$M) } & Mean & 243.7 & 276.9 & 366.6 & 0.045 \\
\hline & Median & 96 & 118 & 112 & 0.092 \\
\hline & $\mathrm{N}$ & 4995 & 1741 & 1548 & \\
\hline \multirow{3}{*}{ Duration } & Mean & 5.5 & 5.0 & 4.6 & 0.068 \\
\hline & Median & 5 & 4 & 4 & 0.088 \\
\hline & $\mathrm{N}$ & 3077 & 779 & 691 & \\
\hline \multirow{3}{*}{ Maturity } & Mean & 7.5 & 7.6 & 10.7 & 0.039 \\
\hline & Median & 5 & 5 & 5 & 0.375 \\
\hline & $\mathrm{N}$ & 4993 & 1741 & 1547 & \\
\hline \multirow{3}{*}{ Coupon (annual \%) } & Mean & 4.1 & 5.6 & 4.3 & 0.766 \\
\hline & Median & 3.0 & 5.1 & 3.9 & 0.352 \\
\hline & $\mathrm{N}$ & 2806 & 749 & 673 & \\
\hline \multirow{3}{*}{ Yield to Maturity (\%) } & Mean & 4.2 & 5.5 & 4.7 & 0.382 \\
\hline & Median & 3.1 & 5.0 & 3.9 & 0.277 \\
\hline & $\mathrm{N}$ & 3224 & 1064 & 887 & \\
\hline
\end{tabular}

This table presents issue characteristics by issuing entity (i.e., parent, domestic subsidiary, or foreign subsidiary). Debt issues are aggregated by issuer, year, type, country, and marketplace. The yield to maturity of loans is calculated by adding monthly LIBOR to the average loan spread. Duration, maturity, coupon, and yield to maturity are a principal-weighted average of the aggregated debt issues. The p-values refer to two-sample t-tests of the mean and Wilcoxon tests of the median between issues by domestic firms (both parents and domestic subsidiaries) and foreign subsidiaries. 
Table 4

Univariate Analysis - Country-Level Tax Variables

\begin{tabular}{|c|c|c|c|c|c|c|}
\hline & & & Dom. & & & \\
\hline & & Parent & Sub. & For. Sub. & For. Sub. & \\
\hline & & & & $\begin{array}{c}\text { Parent } \\
\text { Country } \\
\text { Variables }\end{array}$ & $\begin{array}{c}\text { Sub. } \\
\text { Country } \\
\text { Variables }\end{array}$ & p-values \\
\hline Corporate Tax Rate & Mean & 32.56 & 30.74 & 33.45 & 31.40 & 0.238 \\
\hline & Median & 33.00 & 30.00 & 35.00 & 35.00 & 0.421 \\
\hline Income Tax Rate & Mean & 40.30 & 38.38 & 44.03 & 36.75 & 0.006 \\
\hline & Median & 40.00 & 40.00 & 48.09 & 39.60 & 0.009 \\
\hline Capital Gain Tax Rate & Mean & 21.77 & 18.08 & 17.44 & 17.60 & 0.634 \\
\hline & Median & 20.00 & 20.00 & 20.00 & 20.00 & 0.749 \\
\hline Debt Tax Gain & Mean & -0.14 & -0.14 & -0.21 & -0.10 & 0.000 \\
\hline & Median & -0.12 & -0.15 & -0.25 & -0.08 & 0.000 \\
\hline Miller Gains-to-Leverage & Mean & 0.10 & 0.06 & 0.00 & 0.10 & 0.000 \\
\hline & Median & 0.10 & 0.07 & 0.07 & 0.14 & 0.000 \\
\hline Dividend Imputation System & Mean & 0.33 & 0.42 & 0.40 & 0.22 & 0.004 \\
\hline & Median & 0.00 & 0.00 & 0.00 & 0.00 & 0.068 \\
\hline Dividend Relief System & Mean & 0.03 & 0.04 & 0.01 & 0.09 & 0.104 \\
\hline & Median & 0.00 & 0.00 & 0.00 & 0.00 & 0.243 \\
\hline Dividend Witholding Tax Rate & Mean & na & na & na & 11.77 & na \\
\hline & Median & na & na & na & 15.00 & na \\
\hline Interest Witholding Tax Rate & Mean & na & na & na & 7.60 & na \\
\hline & Median & na & na & na & 10.00 & na \\
\hline
\end{tabular}

This table provides issue-level summary statistics for tax-based incentive variables. For each external debt issue, the table reports means and medians by issuer entity. The first column identifies parent-level issues and tabulates the summary statistics using parent country information. The second column reports parent country information for external debt issued by subsidiaries located in the same country of the parent. The next two columns identify external debt issued by foreign subsidiaries and provide summary statistics using both country-level information from the parent country and the foreign subsidiary country, respectively. The p-values refer to two-sample t-tests of the mean and Wilcoxon tests of the median of country-level information between the parent and foreign subsidiary countries for external debt issued by foreign subsidiaries. All variables are defined in the Appendix. 
Table 5

Univariate Analysis - Firm-Level Variables

\begin{tabular}{|c|c|c|c|c|}
\hline & & $\begin{array}{l}\text { Parent and } \\
\text { Dom. Sub. }\end{array}$ & For. Sub. & p-values \\
\hline \multirow{3}{*}{ Total Assets } & Mean & 10797 & 42884 & 0.000 \\
\hline & Median & 2695 & 29552 & 0.000 \\
\hline & $\mathrm{N}$ & 6263 & 1417 & \\
\hline \multirow{3}{*}{ Total Sales } & Mean & 9250 & 45302 & 0.000 \\
\hline & Median & 2070 & 26755 & 0.000 \\
\hline & $\mathrm{N}$ & 6249 & 1412 & \\
\hline \multirow{3}{*}{ Leverage } & Mean & 0.65 & 0.73 & 0.078 \\
\hline & Median & 0.66 & 0.76 & 0.053 \\
\hline & $\mathrm{N}$ & 6263 & 1415 & \\
\hline \multirow{3}{*}{ ROA } & Mean & 0.09 & 0.09 & 0.856 \\
\hline & Median & 0.09 & 0.09 & 0.933 \\
\hline & $\mathrm{N}$ & 6262 & 1417 & \\
\hline \multirow{3}{*}{ ROA st dev } & Mean & 0.06 & 0.04 & 0.425 \\
\hline & Median & 0.04 & 0.03 & 0.569 \\
\hline & $\mathrm{N}$ & 6262 & 1417 & \\
\hline \multirow{3}{*}{$\begin{array}{l}\text { Interest } \\
\text { Coverage }\end{array}$} & Mean & 7.77 & 4.72 & 0.043 \\
\hline & Median & 3.22 & 2.97 & 0.164 \\
\hline & $\mathrm{N}$ & 6195 & 1405 & \\
\hline \multirow{3}{*}{ Asset Tangibility } & Mean & 0.40 & 0.31 & 0.034 \\
\hline & Median & 0.37 & 0.29 & 0.048 \\
\hline & $\mathrm{N}$ & 6263 & 1417 & \\
\hline \multirow{3}{*}{ Market to Book } & Mean & 7.81 & 4.20 & 0.080 \\
\hline & Median & 1.52 & 1.52 & 0.695 \\
\hline & $\mathrm{N}$ & 4344 & 715 & \\
\hline \multirow{3}{*}{$\begin{array}{l}\text { Effective Tax } \\
\text { Rate }\end{array}$} & Mean & 0.29 & 0.20 & 0.059 \\
\hline & Median & 0.33 & 0.35 & 0.478 \\
\hline & $\mathrm{N}$ & 6258 & 1417 & \\
\hline \multirow{3}{*}{ Asset Maturity } & Mean & 26.56 & 10.73 & 0.027 \\
\hline & Median & 12.48 & 8.32 & 0.048 \\
\hline & $\mathrm{N}$ & 4471 & 1023 & \\
\hline
\end{tabular}

This table provides mean, median, number of observations, and p-value of two-sample t-tests of the mean and Wilcoxon tests of the median for the firm-level control variables. External debt issues are identified on the basis of the country of the entity that offered the security, i.e., domestic firm (parent or subsidiary), or foreign subsidiary. All firm-level controls are measured using parent-level information available in the year preceding the debt issue. All variables are defined in the Appendix. 
Table 6

Correlation Table

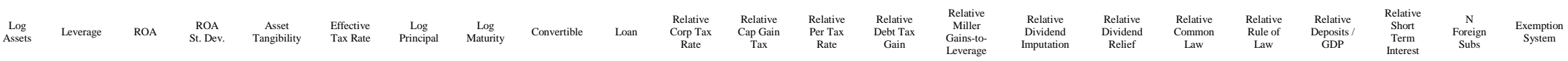

\begin{tabular}{|c|c|c|c|c|c|c|c|c|c|c|c|c|c|c|c|c|c|c|c|c|c|c|c|}
\hline Log Assets & 1.000 & & & & & & & & & & & & & & & & & & & & & & \\
\hline Leverage & 0.426 & 1.000 & & & & & & & & & & & & & & & & & & & & & \\
\hline ROA & 0.072 & -0.177 & 1.000 & & & & & & & & & & & & & & & & & & & & \\
\hline ROA St. Dev. & -0.198 & -0.086 & -0.174 & 1.000 & & & & & & & & & & & & & & & & & & & \\
\hline Asset Tangibility & 0.028 & -0.095 & 0.124 & -0.057 & 1.000 & & & & & & & & & & & & & & & & & & \\
\hline Effective Tax Rate & -0.001 & 0.010 & 0.009 & -0.011 & -0.012 & 1.000 & & & & & & & & & & & & & & & & & \\
\hline Log Principal & 0.465 & 0.080 & 0.149 & -0.098 & 0.154 & -0.007 & 1.000 & & & & & & & & & & & & & & & & \\
\hline Log Maturity & 0.091 & -0.034 & 0.036 & -0.043 & 0.131 & 0.015 & 0.316 & 1.000 & & & & & & & & & & & & & & & \\
\hline Convertible & -0.253 & -0.110 & -0.145 & 0.121 & -0.111 & 0.014 & -0.088 & 0.020 & 1.000 & & & & & & & & & & & & & & \\
\hline Loan & -0.192 & -0.086 & 0.057 & 0.000 & 0.021 & -0.019 & -0.012 & -0.181 & -0.261 & 1.000 & & & & & & & & & & & & & \\
\hline Relative Corp Tax Rate & -0.022 & -0.079 & 0.025 & 0.032 & 0.037 & 0.025 & 0.085 & -0.046 & -0.017 & 0.067 & 1.000 & & & & & & & & & & & & \\
\hline Relative Cap Gain Tax & -0.117 & -0.034 & -0.002 & 0.012 & 0.051 & 0.047 & 0.036 & 0.014 & 0.054 & 0.039 & 0.202 & 1.000 & & & & & & & & & & & \\
\hline Relative Per Tax Rate & -0.154 & -0.151 & 0.028 & 0.036 & 0.091 & 0.015 & 0.039 & 0.022 & 0.009 & 0.134 & 0.569 & 0.316 & 1.000 & & & & & & & & & & \\
\hline Relative Debt Tax Gain & 0.248 & 0.161 & -0.020 & -0.030 & -0.115 & 0.000 & 0.021 & -0.065 & -0.060 & -0.121 & 0.132 & -0.347 & -0.634 & 1.000 & & & & & & & & & \\
\hline Relative Miller Gains-to-Leverage & 0.207 & 0.095 & 0.007 & -0.020 & -0.064 & 0.011 & 0.086 & -0.050 & -0.033 & -0.059 & 0.295 & 0.630 & -0.255 & 0.655 & 1.000 & & & & & & & & \\
\hline Relative Dividend Imputation & -0.067 & 0.010 & -0.069 & 0.001 & -0.059 & 0.005 & -0.116 & 0.009 & 0.019 & -0.013 & -0.093 & 0.433 & 0.098 & -0.242 & -0.048 & 1.000 & & & & & & & \\
\hline Relative Dividend Relief & 0.085 & 0.049 & -0.018 & -0.015 & -0.040 & -0.022 & 0.011 & -0.025 & -0.008 & 0.000 & -0.288 & -0.199 & -0.317 & 0.115 & 0.046 & -0.190 & 1.000 & & & & & & \\
\hline Relative Common Law & 0.349 & 0.199 & -0.037 & -0.059 & -0.159 & -0.005 & 0.044 & 0.004 & -0.089 & -0.142 & -0.176 & 0.031 & -0.323 & 0.334 & 0.400 & 0.127 & 0.077 & 1.000 & & & & & \\
\hline Relative Rule of Law & 0.030 & 0.036 & -0.016 & 0.015 & -0.022 & 0.000 & 0.023 & -0.018 & -0.032 & -0.077 & 0.202 & -0.208 & -0.024 & 0.161 & 0.093 & -0.042 & -0.122 & 0.254 & 1.000 & & & & \\
\hline Relative Deposits / GDP & -0.051 & -0.028 & -0.007 & 0.013 & 0.004 & -0.001 & 0.004 & 0.005 & 0.047 & 0.011 & 0.023 & 0.059 & 0.026 & 0.000 & 0.119 & 0.036 & 0.374 & -0.181 & 0.188 & 1.000 & & & \\
\hline Relative Short Term Interest & 0.178 & 0.099 & -0.024 & -0.033 & -0.059 & 0.001 & -0.033 & 0.032 & -0.051 & -0.042 & -0.311 & -0.039 & -0.211 & 0.106 & 0.039 & 0.091 & 0.041 & 0.279 & -0.120 & -0.094 & 1.000 & & \\
\hline N Foreign Subs & 0.522 & 0.184 & 0.019 & -0.118 & -0.266 & 0.007 & 0.129 & -0.006 & -0.074 & -0.141 & 0.006 & -0.103 & -0.172 & 0.248 & 0.307 & -0.093 & 0.062 & 0.380 & 0.008 & -0.078 & 0.154 & 1.000 & \\
\hline Exemption System & -0.014 & -0.176 & 0.146 & 0.032 & 0.051 & -0.007 & 0.157 & 0.065 & -0.040 & 0.128 & 0.088 & -0.016 & 0.088 & -0.004 & 0.124 & -0.207 & 0.021 & -0.059 & -0.052 & 0.065 & -0.065 & 0.109 & 1.000 \\
\hline
\end{tabular}

This table presents the correlations among the variables used in the multivariate analysis. All variables are defined in the Appendix. 
Table 7

\section{Logistic Analysis of the Corporate Debt Location Choice} between Parent and Foreign Subsidiary

\begin{tabular}{|c|c|c|c|c|c|}
\hline & (1) & (2) & (3) & (4) & (5) \\
\hline \multirow[t]{2}{*}{ Intercept } & -2.04 & -6.06 & -7.08 & -24.49 & -24.14 \\
\hline & $(0.000)$ & $(0.000)$ & $(0.000)$ & $(0.000)$ & $(0.000)$ \\
\hline \multirow[t]{2}{*}{ Log Assets } & & 0.50 & 0.49 & 0.24 & 0.08 \\
\hline & & $(0.000)$ & $(0.000)$ & $(0.000)$ & $(0.272)$ \\
\hline \multirow[t]{2}{*}{ Leverage } & & -0.40 & -0.43 & -1.24 & -1.22 \\
\hline & & $(0.198)$ & $(0.194)$ & $(0.029)$ & $(0.067)$ \\
\hline \multirow[t]{2}{*}{ ROA } & & 1.70 & 1.61 & 1.82 & 1.52 \\
\hline & & $(0.021)$ & $(0.033)$ & $(0.107)$ & $(0.278)$ \\
\hline \multirow[t]{2}{*}{ ROA St. Dev. } & & -2.01 & -2.62 & 0.05 & 1.09 \\
\hline & & $(0.010)$ & $(0.001)$ & $(0.934)$ & $(0.466)$ \\
\hline \multirow{2}{*}{ Asset Tangibility } & & -1.60 & -1.65 & -1.62 & -0.50 \\
\hline & & $(0.000)$ & $(0.000)$ & $(0.000)$ & $(0.336)$ \\
\hline \multirow[t]{2}{*}{ Effective Tax Rate } & & -0.01 & -0.01 & -0.01 & -0.02 \\
\hline & & $(0.521)$ & $(0.559)$ & $(0.274)$ & $(0.252)$ \\
\hline \multirow[t]{2}{*}{ Sub/Parent Leverage } & & & -0.32 & 0.85 & 0.73 \\
\hline & & & $(0.407)$ & $(0.133)$ & $(0.130)$ \\
\hline \multirow[t]{2}{*}{ Sub/Parent ROA } & & & 0.26 & 0.14 & 0.63 \\
\hline & & & $(0.010)$ & $(0.019)$ & $(0.000)$ \\
\hline \multirow{2}{*}{ Sub/Parent Loss } & & & 0.92 & 0.58 & -0.06 \\
\hline & & & $(0.314)$ & $(0.556)$ & $(0.967)$ \\
\hline \multirow[t]{2}{*}{ Log Principal } & & -0.13 & -0.12 & -0.12 & -0.12 \\
\hline & & $(0.001)$ & $(0.001)$ & $(0.083)$ & $(0.111)$ \\
\hline \multirow{2}{*}{ Log Maturity } & & 0.07 & 0.08 & 0.05 & 0.05 \\
\hline & & $(0.177)$ & $(0.147)$ & $(0.675)$ & $(0.671)$ \\
\hline \multirow{2}{*}{ Convertible } & & -1.15 & -1.10 & -0.82 & -0.50 \\
\hline & & $(0.000)$ & $(0.000)$ & $(0.069)$ & $(0.294)$ \\
\hline \multirow[t]{2}{*}{ Loan } & & 0.25 & 0.23 & 0.45 & 0.50 \\
\hline & & $(0.027)$ & $(0.037)$ & $(0.016)$ & $(0.019)$ \\
\hline \multirow{2}{*}{ Relative Debt Tax Gain } & 10.07 & 2.54 & 1.77 & 2.33 & 1.84 \\
\hline & $(0.000)$ & $(0.000)$ & $(0.000)$ & $(0.003)$ & $(0.05)$ \\
\hline \multirow[t]{2}{*}{ Relative Dividend Imputation } & -0.81 & -1.48 & -1.39 & -6.02 & -6.15 \\
\hline & $(0.000)$ & $(0.000)$ & $(0.000)$ & $(0.000)$ & $(0.000)$ \\
\hline \multirow[t]{2}{*}{ Relative Dividend Relief } & 0.55 & 0.21 & 0.87 & -0.67 & -1.33 \\
\hline & $(0.260)$ & $(0.673)$ & $(0.478)$ & $(0.323)$ & $(0.083)$ \\
\hline \multirow[t]{2}{*}{ Exemption System } & 0.23 & 0.65 & 0.11 & 1.38 & 1.40 \\
\hline & $(0.001)$ & $(0.008)$ & $(0.128)$ & $(0.000)$ & $(0.000)$ \\
\hline \multirow[t]{2}{*}{ Relative Common Law } & & & & 3.70 & 3.55 \\
\hline & & & & $(0.000)$ & $(0.000)$ \\
\hline \multirow[t]{2}{*}{ Relative Rule of Law } & & & & 5.16 & 5.03 \\
\hline & & & & $(0.000)$ & $(0.000)$ \\
\hline \multirow[t]{2}{*}{ Relative Deposits / GDP } & & & & 2.23 & 2.12 \\
\hline & & & & $(0.000)$ & $(0.000)$ \\
\hline \multirow[t]{2}{*}{ Relative Short Term Interest } & & & & 8.88 & 8.76 \\
\hline & & & & $(0.000)$ & $(0.000)$ \\
\hline N Foreign Subs & & & & & 0.01 \\
\hline & & & & & $(0.000)$ \\
\hline $\mathrm{N}$ & 8248 & 7546 & 7546 & 6915 & 4756 \\
\hline Pseudo $\mathrm{R}^{2}$ & 0.20 & 0.42 & 0.46 & 0.58 & 0.62 \\
\hline
\end{tabular}

This table presents logistic regressions of the corporate debt location choice. The dependent variable is zero if the debt is issued by either the parent or a domestic subsidiary and one if it is issued by a foreign subsidiary. Across each regression model, we control for year and firm fixed effects. We avoid dropping observations with missing Sub/Parent variables by setting the missing variables to zero and introducing unreported indicator variables set to unity for the missing observations. All variables are defined in the Appendix. P-values are reported in parenthesis. Statistically significant coefficients, at a minimum $10 \%$ confidence level, are reported in bold. 
Table 8

Tobit Analysis of the Amount of Corporate Debt Issued in Different Foreign Subsidiary Countries

\begin{tabular}{|c|c|c|c|c|}
\hline & (1) & (2) & (3) & (4) \\
\hline Intercept & $\begin{array}{c}\mathbf{- 2 . 1 9} \\
(0.000)\end{array}$ & $\begin{array}{c}\mathbf{- 4 . 1 0} \\
(0.000)\end{array}$ & $\begin{array}{c}\mathbf{- 4 . 9 6} \\
(0.000)\end{array}$ & $\begin{array}{c}\mathbf{- 5 . 1 8} \\
(0.000)\end{array}$ \\
\hline Log Assets & & $\begin{array}{c}\mathbf{0 . 1 6} \\
(0.000)\end{array}$ & $\begin{array}{c}\mathbf{0 . 2 0} \\
(0.000)\end{array}$ & $\begin{array}{c}\mathbf{0 . 1 6} \\
(0.000)\end{array}$ \\
\hline Leverage & & $\begin{array}{c}\mathbf{0 . 3 0} \\
(0.076)\end{array}$ & $\begin{array}{c}0.22 \\
(0.316)\end{array}$ & $\begin{array}{c}\mathbf{0 . 7 3} \\
(0.005)\end{array}$ \\
\hline ROA & & $\begin{array}{c}-0.22 \\
(0.537)\end{array}$ & $\begin{array}{c}-0.53 \\
(0.331)\end{array}$ & $\begin{array}{c}0.48 \\
(0.442)\end{array}$ \\
\hline ROA St. Dev. & & $\begin{array}{c}1.74 \\
(0.000)\end{array}$ & $\begin{array}{c}1.23 \\
(0.036)\end{array}$ & $\begin{array}{c}\mathbf{1 . 7 6} \\
(0.006)\end{array}$ \\
\hline Asset Tangibility & & $\begin{array}{c}0.67 \\
(0.204)\end{array}$ & $\begin{array}{c}0.60 \\
(0.198)\end{array}$ & $\begin{array}{c}0.31 \\
(0.130)\end{array}$ \\
\hline Effective Tax Rate & & $\begin{array}{c}-0.01 \\
(0.144)\end{array}$ & $\begin{array}{c}0.00 \\
(0.790)\end{array}$ & $\begin{array}{c}0.00 \\
(0.658)\end{array}$ \\
\hline Debt Tax Gain R & $\begin{array}{c}\mathbf{0 . 2 8} \\
(0.002)\end{array}$ & $\begin{array}{c}\mathbf{0 . 2 1} \\
(0.008)\end{array}$ & $\begin{array}{c}\mathbf{0 . 1 6} \\
(0.082)\end{array}$ & $\begin{array}{c}\mathbf{0 . 1 9} \\
(0.049)\end{array}$ \\
\hline Dividend Imputation $\mathrm{R}$ & $\begin{array}{c}\mathbf{- 0 . 1 5} \\
(0.000)\end{array}$ & $\begin{array}{c}\mathbf{- 0 . 1 7} \\
(0.000)\end{array}$ & $\begin{array}{c}\mathbf{- 0 . 4 2} \\
(0.000)\end{array}$ & $\begin{array}{c}-\mathbf{0 . 2 3} \\
(0.000)\end{array}$ \\
\hline Dividend Relief R & $\begin{array}{c}-\mathbf{- 0 . 3 0} \\
(0.000)\end{array}$ & $\begin{array}{c}\mathbf{- 0 . 3 5} \\
(0.000)\end{array}$ & $\begin{array}{c}\mathbf{- 0 . 7 0} \\
(0.000)\end{array}$ & $\begin{array}{c}\mathbf{- 0 . 5 4} \\
(0.000)\end{array}$ \\
\hline Dividend Withholding & $\begin{array}{c}0.00 \\
(0.361)\end{array}$ & $\begin{array}{c}\mathbf{0 . 0 1} \\
(0.042)\end{array}$ & $\begin{array}{c}\mathbf{0 . 0 1} \\
(0.002)\end{array}$ & $\begin{array}{c}\mathbf{0 . 0 1} \\
(0.040)\end{array}$ \\
\hline Interest Withholding & $\begin{array}{c}\mathbf{- 0 . 0 2} \\
(0.000)\end{array}$ & $\begin{array}{c}\mathbf{- 0 . 0 2} \\
(0.000)\end{array}$ & $\begin{array}{c}\mathbf{- 0 . 0 1} \\
(0.001)\end{array}$ & $\begin{array}{c}\mathbf{- 0 . 0 1} \\
(0.002)\end{array}$ \\
\hline Exemption System & 0.12 & 0.17 & 0.13 & 0.19 \\
\hline Common Law R & $(0.008)$ & $(0.001)$ & $\begin{array}{c}(0.088) \\
-0.04 \\
(0.504)\end{array}$ & $\begin{array}{c}(0.019) \\
-0.09 \\
(0.310)\end{array}$ \\
\hline Rule of Law R & & & $\begin{array}{c}\mathbf{1 . 1 6} \\
(0.000)\end{array}$ & $\begin{array}{c}1.19 \\
(0.000)\end{array}$ \\
\hline Deposits / GDP R & & & $\begin{array}{c}-0.28 \\
(0.367)\end{array}$ & $\begin{array}{c}-0.45 \\
(0.288)\end{array}$ \\
\hline Short Term Interest $\mathrm{R}$ & & & $\begin{array}{c}-0.42 \\
(0.157)\end{array}$ & $\begin{array}{c}-0.36 \\
(0.271)\end{array}$ \\
\hline $\mathrm{N}$ Subs in Country & & & & $\begin{array}{c}\mathbf{0 . 0 4} \\
(0.000) \\
\end{array}$ \\
\hline $\mathrm{N}$ (uncensored) & 683 & 672 & 426 & 294 \\
\hline Log-Likelihood & -3039.6 & -2908.0 & -1733.3 & -1127.8 \\
\hline
\end{tabular}

This table presents a Tobit regression of the amount of corporate debt issued in different foreign subsidiary countries. The dependent variable is the ratio of the amount of debt issued by all foreign subsidiaries of a company located in a specific country to the total amount of debt issued by the corporation in a fiscal year. Since companies issue debt only in a limited set of foreign countries, the dependent variable of the regression is left-censored at zero. Across each regression model, we control for year and firm fixed effects. All variables are defined in the Appendix. P-values are reported in parenthesis. Statistically significant coefficients, at a minimum $10 \%$ confidence level, are reported in bold. 
Table 9

Robustness Check - Logistic Analysis of the Corporate Debt Location Choice between Parent and Foreign Subsidiary excluding Japanese Corporations

\begin{tabular}{|c|c|c|c|c|c|}
\hline & $(1)$ & $(2)$ & (3) & (4) & $(5)$ \\
\hline \multirow[t]{2}{*}{ Intercept } & -2.66 & -6.86 & -7.48 & -21.75 & -20.47 \\
\hline & $(0.000)$ & $(0.000)$ & $(0.000)$ & $(0.000)$ & $(0.000)$ \\
\hline \multirow[t]{2}{*}{ Log Assets } & & 0.42 & 0.40 & 0.26 & 0.09 \\
\hline & & $(0.000)$ & $(0.000)$ & $(0.000)$ & $(0.229)$ \\
\hline \multirow[t]{2}{*}{ Leverage } & & -0.20 & -0.21 & -1.16 & -1.25 \\
\hline & & $(0.618)$ & $(0.599)$ & $(0.042)$ & $(0.066)$ \\
\hline \multirow[t]{2}{*}{ ROA } & & 1.35 & 1.31 & 1.72 & 1.23 \\
\hline & & $(0.140)$ & $(0.143)$ & $(0.142)$ & $(0.387)$ \\
\hline \multirow[t]{2}{*}{ ROA St. Dev. } & & -0.02 & -0.02 & -0.04 & 1.11 \\
\hline & & $(0.955)$ & $(0.963)$ & $(0.952)$ & $(0.421)$ \\
\hline \multirow[t]{2}{*}{ Asset Tangibility } & & -1.29 & -1.28 & -1.72 & -0.50 \\
\hline & & $(0.000)$ & $(0.000)$ & $(0.000)$ & $(0.334)$ \\
\hline \multirow[t]{2}{*}{ Effective Tax Rate } & & -0.01 & -0.01 & -0.01 & -0.01 \\
\hline & & $(0.616)$ & $(0.635)$ & $(0.400)$ & $(0.410)$ \\
\hline \multirow[t]{2}{*}{ Sub/Parent Leverage } & & & -0.87 & -0.35 & -0.02 \\
\hline & & & $(0.027)$ & $(0.565)$ & $(0.978)$ \\
\hline \multirow[t]{2}{*}{ Sub/Parent ROA } & & & 0.84 & 1.07 & 1.01 \\
\hline & & & $(0.000)$ & $(0.000)$ & $(0.001)$ \\
\hline \multirow[t]{2}{*}{ Sub/Parent Loss } & & & -0.47 & -0.33 & -0.94 \\
\hline & & & $(0.362)$ & $(0.768)$ & $(0.524)$ \\
\hline \multirow[t]{2}{*}{ Log Principal } & & -0.13 & -0.13 & -0.13 & -0.14 \\
\hline & & $(0.003)$ & $(0.004)$ & $(0.056)$ & $(0.077)$ \\
\hline \multirow[t]{2}{*}{ Log Maturity } & & 0.13 & 0.15 & 0.09 & 0.11 \\
\hline & & $(0.102)$ & $(0.041)$ & $(0.416)$ & $(0.405)$ \\
\hline \multirow[t]{2}{*}{ Convertible } & & -0.02 & -0.02 & -0.54 & -0.12 \\
\hline & & $(0.886)$ & $(0.927)$ & $(0.230)$ & $(0.807)$ \\
\hline \multirow[t]{2}{*}{ Loan } & & 0.34 & 0.30 & 0.53 & 0.72 \\
\hline & & $(0.014)$ & $(0.022)$ & $(0.004)$ & $(0.001)$ \\
\hline \multirow[t]{2}{*}{ Relative Debt Tax Gain } & 1.95 & 1.44 & 0.83 & 0.73 & 1.12 \\
\hline & $(0.000)$ & $(0.018)$ & $(0.043)$ & $(0.044)$ & $(0.032)$ \\
\hline \multirow[t]{2}{*}{ Relative Dividend Imputation } & -3.67 & -2.98 & -2.90 & -5.84 & -5.98 \\
\hline & $(0.000)$ & $(0.000)$ & $(0.000)$ & $(0.000)$ & $(0.000)$ \\
\hline \multirow[t]{2}{*}{ Relative Dividend Relief } & 1.18 & 0.98 & 1.06 & -0.59 & -1.37 \\
\hline & $(0.176)$ & $(0.311)$ & $(0.278)$ & $(0.356)$ & $(0.065)$ \\
\hline \multirow[t]{2}{*}{ Exemption System } & 0.66 & 0.65 & 0.65 & 1.02 & 1.05 \\
\hline & $(0.000)$ & $(0.000)$ & $(0.000)$ & $(0.000)$ & $(0.000)$ \\
\hline \multirow[t]{2}{*}{ Relative Common Law } & & & & 3.31 & 2.90 \\
\hline & & & & $(0.000)$ & $(0.000)$ \\
\hline \multirow[t]{2}{*}{ Relative Rule of Law } & & & & 4.70 & 4.61 \\
\hline & & & & $(0.000)$ & $(0.000)$ \\
\hline \multirow[t]{2}{*}{ Relative Deposits / GDP } & & & & 2.06 & 1.94 \\
\hline & & & & $(0.000)$ & $(0.000)$ \\
\hline \multirow[t]{2}{*}{ Relative Short Term Interest } & & & & 7.20 & 6.44 \\
\hline & & & & $(0.000)$ & $(0.000)$ \\
\hline N Foreign Subs & & & & & 0.02 \\
\hline & & & & & $(0.000)$ \\
\hline $\mathrm{N}$ & 4931 & 3744 & 3744 & 2693 & 2693 \\
\hline Pseudo $\mathrm{R}^{2}$ & 0.26 & 0.43 & 0.46 & 0.51 & 0.49 \\
\hline
\end{tabular}

This table presents logistic regressions of the corporate debt location choice. The dependent variable is zero if the debt is issued by either the parent or a domestic subsidiary and one if it is issued by a foreign subsidiary. Across each regression model, we control for year and firm fixed effects. We avoid dropping observations with missing Sub/Parent variables by setting the missing variables to zero and introducing unreported indicator variables set to unity for the missing observations. All variables are defined in the Appendix. Pvalues are reported in parenthesis. Statistically significant coefficients, at a minimum $10 \%$ confidence level, are reported in bold. 